\title{
5
}

\section{Sophokles' Philoktetes and the Teachings of the Sophists: A Counteroffensive}

Unaccommodated man is no more but such a poor, bare, forkt animal as thou art.

-William Shakespeare

The Tragedy of King Lear

The work of Aeschylus represents, in the trajectory from Homer to Plato, the apogee of progressive ideology manifested in a form, the tragic trilogy, which was capable of embodying at least the utopian hope of forward movement-however painful-out of the brutal hierarchies inherited from the past. That past and that hope were conceived of in eminently social and political terms, terms to which the vast and mysterious conglomeration of forces beyond human control, the gods, was seen with cautious optimism as somehow ultimately ("in time") amenable. The old gods, whose erotic adventures with mortals were alleged to be warrants for ruling-class privilege, have been swept away along with a whole array of older determinisms. Sophokles (496-4o6 B.c.), roughly a quarter-century younger than Aeschylus, presumably learned much from Aeschylus, against whom he won his first victory as a tragedian in 468 B.c. Yet his extant plays, dating from the early 440 s to the end of his life, confront the modern reader with a fundamentally different sense of the tragic form and a disconcertingly different vision of human society and the forces beyond human control.

\section{Sophokles and Aeschylus}

Sophokles' relationship to Aeschylus has been much discussed. Of relatively recent treatments, Winnington-Ingram has made the most compelling case for the centrality of some Aeschylean issues in Sophokles and in particular a significant return to Aeschylean issues at the end 
of Sophokles' career (1980: $324-27){ }^{1}$ At the same time, WinningtonIngram chooses to emphasize as the final and, one may presume, somehow dominant characteristic of Sophokles his irony-a perspective to which "we find little response ... among the adherents of any optimistic philosophy" (329). Winnington-Ingram himself has only a little before acknowledged that Aeschylus' own "solution" is "partly in terms of society, and of the evolution of society" ( 325 ; cf. 1983: 16674). We thus find within the same eminent critic's assessment both a case for significant continuities and, at the most abstract and fundamental level of worldview, a sharp disjuncture.

Irony may seem an abstract point indeed at which to begin our consideration of Sophokles, but it has the virtue of raising some fundamental questions that any Marxist reading of Sophokles ignores at its peril. Winnington-Ingram tries to sum up, on the last page of his study of Sophokles, his own sense of Sophoklean irony by giving a few condensed instances of situational irony from the plays and repeating the phrase, "But the world is like that!" (1980: 329). Before we generalize an ahistorical world, we need to inquire what an ironic response implies about the social and political world in which Sophokles lived and acted and for which he composed some hundred and twenty tragedies during his long career. It would be wrong, I believe, to conclude from Sophokles' irony that his texts demonstrate any denial or lack of awareness of dramatic changes in the social and political arena. Few would deny the centrality of such change in the Ajax or Philoktetes. Rather, the irony seems to derive in no small measure from invoking a transcendent realm from which more permanent realities of the world emerge as inherently intractable to mere human efforts, either at comprehension or control. Inscrutable and essentially inaccessible forces beyond human control render ironic the human struggles to impose human meaning and human values on the world. This at least is what I take to be the gist of Winnington-Ingram's view of Sophokles. ${ }^{2}$ It is this irony with which Winnington-Ingram attempts to transcend the fundamental contradiction in interpretations of Sophokles between those who

'I single out for extended comment the work of Winnington-Ingram because he has contributed in major ways to our understanding of both Aeschylus and Sophokles. Whatever my disagreements with him, I have always found his work not only wonderfully learned but deeply wise and honest. Though he is clearly unsympathetic to any political reading of Sophokles (cf. 1980: 308-11), he acknowledges much of the key evidence in the texts. Though he has much sympathy for what he takes to be the religious tenor of Sophokles' worldview, he is too good a philologist to ignore the specific Greek words used for various divine forces-never falling into that infallible sign of the pietists, the use of "God" with a capital $G$ to translate Zeus or Ho theos or hoi theoi or ho daimonn.

${ }^{2}$ This seems as well to be the direction of George Steiner's contribution to the discussion of Knox's paper "Sophokles and the Polis" (Knox 1983: 30). 
view the plays as justifications of the actions of their massive protagonists (the "hero-worshipers") and those who find a religiously inspired critique of heroism at the heart of the tragedies (the "pietists"; 1980: 9, 322-23; see Johansen 1962: 152). According to Winnington-Ingram, the heroes are critiqued from a religious perspective for their "pathology of heroism" (305), yet their intransigence in pursuit of retaliation for wrongs (the talio) brings them into a unique proximity to that very vindictiveness in the gods $(326-27)$.

Sophokles' most obvious continuity with Aeschylus, one perhaps too easily seen as simply inherent in tragedy, is his focus, again most obvious in the Ajax and Philoktetes, on figures of massive importance to the societies in which they find themselves, figures whose actions have potentially disastrous consequences on their societies. The attributes I attempted to spell out in the preceding chapter as characteristic of the aristocratic, ruling-class type in the Oresteia have long been recognized as components of most Sophoklean heroes (Knox 1964: chaps. 1, 2; cf. Winnington-Ingram 1980: 304-6). These characteristics include pride in aristocratic birth, exceptional daring $(t o l m \bar{e})$, and a single-minded determination to impose their purposes and perspectives on the world without any consideration of the potentially disastrous consequences for the society which, in some sense, is radically dependent on them. Aeschylus, however, despite attempts by Aristophanes to appropriate his name for elitist politics, is scarcely in danger of being perceived as a hero worshiper. The emphasis in his texts on the pathology of heroism is profound. Many have found grounds to sympathize with and excuse Agamemnon. Others have expressed varying degrees of grudging admiration for Klytemnestra. But not even Orestes risks being perceived as a positive paradigm held up for the audience to admire and, to the best of their abilities, emulate. Yet book after book, article after article, appears committed to this alleged "misreading" of Sophokles' heroes. The pietists see Sophokles doing essentially the same thing as Aeschylus-dissecting the pathology of the powerful and dangerous figures and affirming their ultimate punishment by a wise and just divine order. The ironists, like Winnington-Ingram, seem to find an Aeschylean negation of these dangerous aristocratic types but no corresponding affirmation of an imaginable alternative.

This radical break with Aeschylus manifests itself on the formal level as well. We alluded earlier to the impossibility of discovering with certainty whether Aeschylus invented or simply found congenial the form of a trilogy of plays on connected themes. What is quite clear at least from the surviving plays of Sophokles is that Sophokles did not choose to connect three plays. In his extant work there is no place for the audience, or characters in the drama, to take a long view extending be- 
yond the lifetime of the protagonists. To put it differently, for Sophokles only the gods can afford the long view. Aeschylean protagonists conf ront grim choices with vast consequences, but the audience is enabled by the trilogy form to distance itself from the protagonists and focus on the long-term consequences for society as a whole. Sophoklean protagonists tend to sweep the audience into the immediate agony of their existential choices; the unknowability of the consequences is a central element in the "heroism" of the choice.

Aristotle, who tells us that Aeschylus diminished the role of the chorus in favor of more interaction between the speaking characters, also attributes to Sophokles the addition of the third actor. There is a corresponding new diminution of the role of the chorus and an escalated emphasis on the clashing interactions of the protagonists. To the extent that the chorus represents the interests and perspectives of ordinary citizens, we find it strikingly diminished in comparison to Aeschylus.

But perhaps the most remarkable difference between the Aeschylean and Sophoklean protagonists is the latters' sense of their profound isolation and alienation from the community of which they were once a part (Knox 1964: 5, 21-22; Winnington-Ingram 1980: 305-6). Even when, within the dynamics of the play, the chorus are partisans of the protagonists, as in the Ajax or Trachiniae, the dramatist is at pains to underline the incapacity of the chorus to understand what is at stake for the protagonists. Despite the fairly open hostility of the chorus of the Agamemnon, Klytemnestra, like Agamemnon himself, functions as if she is in control and fully capable of communicating with the chorus. Sophoklean protagonists are isolated from that automatic domination of the social and political hierarchy that is so characteristic of Aeschylean heroes.

If we see Aeschylus as engaging in a fundamental ideological assault on the claims of inherited excellence in a context that insists on a world changed decisively by democracy, Sophokles, rather than doing the same thing, seems to me to be exploring the implications of a world in which the old elite has suffered a fundamental ideological critique and an institutional displacement. Heroes who are defined and define themselves in terms of an inherited phusis, who are eugenes and gennaios - the "winners" in every sense for Pindar-in Sophokles are subjected to a withering critique and stripped of all the material and social props of their identity - wealth, power, family, and friends. Most of Sophokles' protagonists begin where Aeschylus' protagonists end: defeated, socially and politically dead. It is as if Sophokles accepted the victory of democracy, granted the validity of much of the Aeschylean critique of the scions of wealth and power, yet set about laying the 
grounds for an ideological counteroffensive. Rather than a simple celebration of the Pindaric type, Sophokles engages his audience in an essentially rhetorical operation in which key points are conceded only to prepare the ground for a new basis on which to insist on the need of society to be dominated morally and politically by uniquely endowed individuals whose very excellences render them impossible for democratic society.

\section{Aristocratic Terminology and the Role of the Sophists}

Part of the thematic shift from Aeschylus to Sophokles is reflected in a radically different usage of the vocabulary of inherited excellencephusus, phuō, eugenēs, gennaios, and so on. As Diller long ago pointed out (1956), there is a conscious juxtaposition in the Sophoklean texts of different senses and implications of these terms and, more striking, a dramatically central consciousness on the part of the protagonists themselves about the implications of their inherited natures. In the $A n$ tigone, for example, the character Antigone perceives and affirms her identity aristocratically in terms of her parentage but presents the validity of that identity as a challenge to her sister: "Such now is your situation, and soon you will show / Whether your innate nature is noble [eugenēs pephukas] or you were bred base from noble parents" (Ant. 3738). Yet Antigone also uses the vocabulary of innate character to describe her ethical stance in terms that either are purely arbitrary or may be understood as a consequence of her gender: "Not to join in hatred, but rather in love is my innate nature" (ephun, 523). There is no ambiguity about Ismene's definition of her identity in terms of gender (gunaikh' hoti / ephumen, 61-62). Haimon speaks of his natural duty as a son $(638)$, and Kreon defines his phusis in terms of his age (726-27). This variety in conceptions of what is "innate" or "natural" for the individual invites the audience to recognize that this traditional vocabulary is now "up for grabs." At the same time, the development of the dramatic action drives us toward associating whatever moral and political value we find in Antigone's position with her aristocratic conception of her phusis.

Similarly, in the Ajax Ajax's wife offers a strikingly unaristocratic conception of nobility (eugeneia, Ajax 485-524). The audience here too is compelled to engage in a battle over the ethical import of this key category of social vocabulary. The whole movement of the drama likewise compels the audience to judge Ajax in the light of his radically, self-consciously aristocratic definition of his inherited nature (Ajax $\left.430-80,545^{-51}\right)$. I would argue, though I cannot demonstrate it here, 
that the rhetorical strategies of both these early plays succeed in valorizing the protagonists' seemingly literal affirmations of their inherited natures by transforming aristocratic vocabulary into a metaphor for some fundamental integrity - an integrity in principle worthy of emulation. De Romilly has ably shown the strain of heroic absolutism in Perikles' Thucydidean speeches $(1963: 110-55)$. This is not to invite a simple equivalence between Sophokles and Perikles (see Ehrenberg 1954) but rather to suggest that there is nothing inherently improbable in such a form of aristocratic demagoguery. What does require further investigation is whether the specific form of Sophoklean heroism makes a statement fundamentally sympathetic or hostile to the egalitarian thrust of democratic ideology. My sense in general is that Sophokles' career might be seen in its entirety as thoughtful questioning of democratic ideological hegemony by an informed participant (Knox 1983: $5,26-27$ ), a questioning haunted by a profound nostalgia for the lost Pindaric vision of society ruled by the innately superior scions of the old propertied families. ${ }^{3}$ He sees the inadequacy of this older vision but finds nothing comparably compelling in the contemporary options. His plays thus imply a negation of what he sees as the status quo. At the same time, here and there we can see hints of a utopian projection of a new aristocratic order, one in which the truly best people-in terms of ethical stature-meet with the appropriate subordination from their inferiors.

In discussing Aeschylean dialectic we alluded to the heated chronological debate over possible sophistic influence. Though such an influence seems highly probable to me, it is possible that Aeschylus independently developed a conception in harmony with key elements of an anthropology worked out in detail somewhat later. What is essential, I believe, is to recognize (along with Havelock 1957) the central role of this anthropology in the elaboration of a specifically democratic alternative to the aristocratic worldview, an alternative that substitutes a common human identity of the children of earth for the hierarchy dominated by the sons of gods.

Sophokles is chronologically the full contemporary of the Sophists during the period of their maximum activity and influence; his response to them has been viewed, with few noteworthy exceptions, as fundamentally hostile. ${ }^{4}$ Wilhelm Nestle seems to have set the pattern

\footnotetext{
${ }^{3} \mathrm{Knox}(1983)$ makes a compelling case for a consistently hostile presentation of the claims of the polis in the Ajax, Antigone, Oedipus Tyrannus, Philoktetes, and Oedipus at Colonos but characteristically ignores the issue of class and, in my view, understates the relevance of the specifically democratic nature of Athens.

${ }^{4}$ Nestle's view is echoed with slight modifications in Busse 1927, which in turn is cited with full approval in Webster 1936: 52. Compare Weinstock 1937: 13, Bowra 1965: 272,
} 
in this century: "He [Sophokles] can go along with it [the Sophistic] a little way, namely, when it concerns itself solely with empirical inquiry. But as soon as the Sophistic sets about drawing conclusions based on the results of its inquiry-conclusions about a worldview and about practical conduct-their paths part. The poet then sees in it the open enemy" (1910: 134; cf. 1940: 451-55). Along the same lines, Sophokles has more recently been characterized as "the last great exponent of the archaic worldview" (Dodds 1951:49). ${ }^{5}$ In a rather striking departure from what one might call the Nestle consensus, Cedric Whitman argued: "If the Sophistic rationalism destroyed Euripides, its effect on Sophocles was quite the reverse.... Sophocles stood his ground and thought through the implications of religion as a human invention and man as the measure of all things. The grace and power with which his intellect moved amid and transcended and rabid theorizing of the avantgarde is one of the miracles of artistic history" (1951: 228-29, emphasis added). Apart from enthusiastic praise by Friis Johansen (1962: 161), Whitman's view had apparently little impact. ${ }^{6}$

In the following analysis, I attempt to take account of Havelock's more political analysis of the Sophists (1957). In the light of that analysis, I examine anew the relation of sophistic thought to Sophokles' Philoktetes. What emerges is a view of Sophokles that implies neither a pious polemic against the Sophists nor a whole-hearted endorsement of their fundamental assumptions. Rather, to use Whitman's phrase, Sophokles "thought through" a great deal more of the sophistic than their attacks on religion or their fascination with rhetoric. In particular, I believe that he was profoundly influenced by their comprehensive materialist analysis of the origin and development of human society

Ehrenberg 1954: 64-66, Opstelten 1952: 67, Pohlenz 1954: 159-6o, Lesky 1972: 272, Kitto 1958: 63, and Craik 1980 .

${ }^{5}$ Dodds goes on to offer a significant qualification: "the true cleavage" marking the end of the Archaic age falls "with the rise of the Sophistic Movement. ... In his thought, though not in his literary technique, Sophokles (save perhaps in his latest plays) still belongs to the older world" (1951: 5 o n. 1). More recently, Dodds goes out of his way to stress his belief that "Sophokles was no humanist, and the Antigone is no Protagorean tract for the times" (1973: 8). Winnington-Ingram's "Tragedy and Greek Archaic Thought" (1965) is described by its author as a gloss on Dodds's view in The Greeks and the Irrational. Though this is far too modest a description, the emphasis is decidedly on the more archaic aspects of Sophokles' assumptions. His comment on Knox's Fondation Hardt contribution (Knox 1983: 33) suggests his continued adherence to this emphasis: "Oedipus' violent condemnation of his won polis is a characteristic product of the irrational workings of his thumos, which increases as he approaches the status of a hèrōs."

${ }^{6}$ This is not to say that no one has offered significant qualifications of the traditional view. For example, Segal $\left(19^{6} 3\right.$ : $38-39 ; 1964,46-66,1981$ : esp. 9) relates Sophokles' view to those of the Sophists along lines similar to my view of the Philoktetes. A. Long concludes: "The use he [Sophokles] made of Presocratic thought, the interest he shows in sophistic attitudes and arguments exemplify a mind which was completely involved in the intellectual life of fifth-century Athens" (1968: 166-67). 
and behavioral patterns, an analysis that had fascinated him at least since the time he composed the Antigone. In his hands, however, it is scarcely grounds for democratic optimism. It becomes rather an existential ground on which he lays the foundation for a refurbished aristocratic ideology, and ideology in which "birth" is still an essential component, but one that seeks to incorporate a full awareness of all the social factors that contribute to the construction of individual character.

\section{Sophistic Anthropology: Three Stages}

It is difficult not to be deterred from even discussing the Sophists by the sheer weight of potential problems: the relative paucity and ambiguity of the sources, the of ten radical differences between the views of particular Sophists on particular topics, the limitations of the very term "Sophist" in dealing with some important topics that were of interest to almost all presocratic thinkers. ${ }^{7}$ Havelock's brilliant presentation of the case for a more comprehensive and fundamentally sympathetic conception of the Sophists met with some intemperate invective (e.g., L. Strauss 1959), but generally, almost worse, with widespread disregard. Yet the broad outlines of his thesis, particularly with regard to the role of anthropological speculation in the Sophists' conception of society, have been confirmed by the punctilious scholarship of Cole and accepted, with only occasional grumblings, by Guthrie. ${ }^{8}$ Perhaps, then, we may concentrate on the process of reevaluating the relation of the Sophists' thought to that of major fifth-century and, as I argue in the next chapter, fourth-century figures. I begin my efforts by offering a brief, necessarily schematic summary of the major

\footnotetext{
${ }^{7}$ Hereafter I use "Sophists" to refer to the whole group of relevant presocratic thinkers.

${ }^{8}$ Guthrie (HGP 3.10 n. 1) cites with apparent approval Leo Strauss's bizarrely ferocious attack (1959) recently embraced by Allan Bloom, who has written an enthusiastic foreword to the recent republication of Strauss's essays (1989). Strauss rejects every major thesis of Havelock's book, especially the existence of a significant body of anthropological speculation in the fifth century. But Guthrie's own treatment of the Sophists remains deeply indebted to Havelock's work and contains (HGP 3.79-84) a usef ul appendix of passages, ultimately derived from the Sophists, descriptive of human progress. As for Cole's work, while some (e.g., Furley 1970: 147; Dodds 1973: 11) have raised doubts about the centrality of Democritos to fifth-century anthropological speculation, there is no longer room for the sort of skepticism expressed by Strauss about the comprehensiveness, subtlety, and extensive influence of this body of thought in the fif th century. In my own discussion I simply cite what I believe is a reasonable sampling of the ancient evidence. For a def ense of the admittedly unclear relevance of some of these sources, the reader may consult the detailed discussions of Havelock (1957: esp. 405-20), Cole (1967), and Guthrie (HGP vol. 3, esp. $5^{1-54}$ and the bibliography at the end of the volume). For a provocative reassessment of the contemporary relevance of the Sophists see Jarratt 1991.
} 
sophistic views of human society and values in order to set in clear relief both Sophokles' indebtedness and his specific ideological response to those views in the Philoktetes.

For the sake of clarity, the sophistic analysis of society may be divided into three stages: the origin of the species and the early struggle to survive in isolation or relative isolation before the invention of the polis; the establishment of a social compact that enabled the development of cities; and the functioning of contemporary-primarily Atheniansocial, economic, and educational mechanisms. ${ }^{9}$

A central feature of the sophistic analysis of society is a materialist anthropology, a speculative account of the origin of human society based on the assumption that human beings arose from the earth and water, began as animals, and like all other animals conf ronted the problems of survival with no special metaphysical or supernatural resources or direction. ${ }^{10}$ Characteristic of sophistic anthropology is a detailed and highly evocative picture of the horrors of human existence at a presocial stage of their evolution. ${ }^{11}$ Isolated and without the natural defenses of other animals against predators and the natural elements, primitive human beings are pictured as engaged in a desperate struggle to find shelter from storms and the winter's cold as well as to contrive weapons for self-defense and for acquiring food, which their natural helplessness rendered a perpetual source of anxiety. The development of hunting, medicine, and agriculture and, above all, the discovery of fire with its associated technologies were presented as the chief means of escaping the worst horrors of the battle for survival. In the various accounts of this presocial stage, a fairly consistent termi-

${ }^{9}$ The so-called great speech of Protagoras in Plato's dialogue of that name, one of the most important sources for the sophistic analysis of society, does in fact divide pretty clearly into these three stages; see $320 c 8-322 \mathrm{~b} 8 ; 322 \mathrm{bg}-\mathrm{d}_{5}$; and $322 \mathrm{~d} 6-328 \mathrm{~d} 2$. In the case of Democritos, Cole (1967) posits that many further substages and some forms of elemental cooperation (e.g., hunting and agriculture) precede the full emergence of the social stage; but his far more detailed analysis is not incompatible with the three broad stages I describe. In the case of other fifth-century thinkers, the evidence is far more fragmentary, but such evidence as there is seems to me to fit well into this general pattern.

${ }^{10}$ Anaximander $D-K$ A 30; Xenophanes $D-K$ B 29 and 33; Anaximenes $D-K$ B 3; Archelaus $D-K$ A 4.5; Democritos $D-K$ A 139; cf. Plato Prot. 321c3-4. The kinship with divinity brought in later (322a3-4) does seem extraneous, and Havelock is probably right to see platonic contamination there (1957: 91-92). The purely materialist description in Diodorus 8.4 of earth's wombs in which embryos form, a passage closely echoed in Lucretius' fif th book, suggests how rigorously even mother earth was stripped of all divinity. It is Pindar, not the Sophists, who insists on the kinship of humans and gods through mother earth (Ne.6.1-2).

"Aeschylus Prometheus Bound 422-68, 476-5o6; Sophokles Ant. 332-64; Euripides Sup. 201-13; On Ancient Medicine 3.20-30; (in Loeb Hippocrates I); Plato Prot. 321c1322b8; Diodorus 1.8; Moschion, Tragicorum Graecorum Fragmenta, ed. A. Nauck, rep. 1964 [1889], sup. by B. Snell. Hildesheim: Georg Olms Verlagsbuchh andlung. 
nology indicates the fundamental ideas. ${ }^{12}$ The driving force is "need" (khreia) or "necessity" (anankē); the only relevant human goal, "survival" (sötêria); the sole criterion, what is "useful" (khrēsimon), "helpful" (ophelimon), or "advantageous" (sumpheron) toward the end of "supplying" (porizō) adequate "sustenance" (trophē) and other fundamental needs. The decisive human contribution to survival is the "practical intelligence" (sophia) that enables human beings to "learn" (manthanō, didaskomai) from chance "discoveries" (heuriskō) and convert them into "contrivances" (mēkhanē) and "technologies" (tekhnēe).

A second stage posited by the sophistic anthropology has frequently been described by the term "social contract" or, as Guthrie pref ers, "social compact" (HGP 3.135 n. 1). Technology and some minimal cooperation might secure the food supply and protection from the elements and beasts, but human beings were still prey to the violence of other human beings. Accordingly, the survival of the race required the establishment of agreed on values and rules of nonaggression (to put it most negatively, see Plato Republic $358 \mathrm{e}_{1}-359 \mathrm{~b} 5$ ) or, as the older and generally more optimistic thinkers put it, bonds of affection (philia), like-mindedness (homonoia), pity (to oikteirein), the substitution of persuasion (peithō) for violence (hubris, bia, kratos), the subordination

${ }^{12}$ I am aware that all the words here cited are extremely common in nonanthropological contexts, and in that sense they do not constitute a special vocabulary. What is noteworthy is the consistent nexus of ideas revealed by the frequent combination of these terms in the anthropological accounts. A portion of Diodorus 1.8, listed by Diels and Kranz among the fragments of Democritos (elaborately defended in Cole 1967, but put earlier by Guthrie, $H G P 1.69, \mathrm{n} .1$ ), suggests the character of this material: "But the first men to be born, they say, led an undisciplined and bestial [thëriōdei] life, setting out one by one [sporadēn] to secure their sustenance and taking for their food both the tenderest herbs and the fruits of wild trees. Then since they were attacked by the wild beasts, they came to each other's aid, being instructed by expediency [hupo tou sumpherontos didaskomenous], and when gathered together in this way by reason of their fear, they gradually came to recognize their mutual characteristics. And though the sounds [tēs phönēs] which they made were at first unintelligible and indistinct, yet gradually they came to give articulation to their speech, and by agreeing with each other upon the symbols for each thing which presented itself to them, made known among themselves the significance which was to be attached to each term.... Now the first men, since none of the things useful for life [tōn pros bion khrēsimōn] had yet been discovered [heurēmenou], led a wretched existence, having no clothing to cover them, knowing not the use of dwelling and fire, and also being totally ignorant of cultivated food. . . Consequently large numbers of them perished in the winters because of the cold and the lack of food. Little by little, however, experience taught them [hupo tês peiras didaskomenous] both to take to the caves in winter and to store such fruits as could be preserved. And when they had become acquainted with fire and other useful things [khresimōn], the arts [tekhnas] also and whatever else is capable of furthering man's social life [ta dunamena ton koinon bion öphelèsai] were gradually discovered [heurethēnai]. Indeed, speaking generally, in all things it was necessity [tēn khreian] itself that became man's teacher [didaskalon], supplying in appropriate fashion instruction [mathēsin] in every matter to a creature which was well endowed by nature [euphuei] and had, as its assistants for every purpose, hands and speech [logon] and sagacity of mind [psuchès ankhinoian]. (Loeb translation) 
of narrowly conceived self-interest (kerdos, to sumpheron) to respect (aidōs) for others, right conduct (dikē), and a sense of the common good (to koinon, to ksunon). ${ }^{13}$ The development of language itself out of inarticulate cries seems associated with this phase in some sources, and others include the development of religion. ${ }^{14}$ Though some later fifthcentury thinkers may have presented this contract stage as a conspiracy of the weak and inferior majority to protect themselves from the superior and stronger few, I believe it is legitimate to say that the dominant note in the accounts of this stage is a benign and idealistic emphasis on the natural unity of the human species, a celebration of all the ties that bind. ${ }^{15}$

In the most complete accounts we have of this early anthropological speculation, the lessons and terminology of the first and second stages are applied to the new realities of the contemporary Greek

13Affection: Aeschylus Prometheus Bound 11, 123 ; Plato Prot. 322C1-3; Democritos D-K B 186, with Cole's discussion (1967: 117 ); Aristotle EN 8.115925-11621 4, with Cole's discussion (1967: 134-38). Like-mindedness: Democritos $D-K$ B 186, 250, 255; Gorgias $D$ $K$ B8; Thrasymachos $D-K$ B 1; Antiphon $D-K$ A 2, B 44a. Pity: Aeschylus Prometheus Bound 239 (the hero's sole motive in helping humankind), see 68, 238, 246, 352, 435, 648 for the persistence of the motif; Democritos $D-K$ B 255, see also B 107 and 293 with Havelock's discussion (1957: 144). Persuasion instead of force: Democritos $D-K$ B 181 ; Gorgias $D-K 11.8$; see also Plato Gorg. 4522d5-e4, Prot. 337a2-b2 (parody of Prodicus) and 337c7-338al (parody of Hippias); Anon. Iamb. 6-7 (see Cole 1960). Association of ethics with the common good: Plato Prot. 322c2-5, e2-323a4; Democritos $D-K$ B 179 , 252, 293; Anon. Iamb. 6-7.

${ }^{14}$ Language: Sophokles Ant. $353-56$, whereas in Diodorus 1.8.3 it precedes fire. Religion: Prodicus $D-K$ B 5 ; Kritias $D-K$ 25.9-15 $=\operatorname{Tr} G_{43} \mathrm{~F}_{19}$ (Snell). It is striking that the Democritean account preserved in Diodorus Siculus 1.7-8 does not include religion despite the author's interest in the topic once he switches to other sources. I therefore find it extremely misleading that Segal begins his lengthy account of the Philoktetes by an implicit indictment of the hero's lack of religion: "In creating a hero whose struggle for survival reflects early man's establishment of civilization, he [Sophokles] omits the institution of worship, a fundamental point in fifth-century speculation on the origin of culture. In this respect, as in others too, the hero is agrios" (1981: 292 emphasis added). Included in Segal's evidence is a clearly Egyptian section in Diodorus (1.16.1). I would say that the most fundamental feature of these accounts is their materialism, not their occasional rationalist account of the origin of religion. It might be more pertinent to note that the first references to religion in the play evoke the purely formal piety that is alleged in justification of the inhuman marooning of Philoktetes $(P h .8-11)$. A similarly misleading emphasis on religion later on in Segal enlists the dubious support of Homeric Hymn 20 to give the impression that "in the anthropology of the Sophists early man 'dwelt in mountainous caves and sunless gullies' (Moschion, frag. 6.4-6, Nauck), 'like beasts' (Homeric Hymn 20) until Athena and Hephaestus taught them the 'shining works' of civilization" (1981: 298). The point of most sophistic accounts-and, I argue, of Sophokles' Philoktetes-is that human beings wrested life from nature without any "graciousness and benevolence of the gods" (cf. 1981: 295).

${ }^{15}$ Plato's Kallikles in the Gorgias $\left(483^{b} b_{4}-c 6\right)$ describes the social contract so forcefully in negative terms that generations of classicists have been convinced that Kallikles is the most accurate articulation of the sophistic view. Indeed, Lintott sees the Sophists only in connection with the "philosophical background to the oligarchic movement" (1982: 168-73). 
and specifically Athenian society. Here again, toward the later part of the fifth century, views expressing deep disillusion or extreme cynicism are associated with specific Sophists and presented as typical, yet the evidence indicates that the major proponents of anthropological theories applied them to a fundamentally optimistic, even utopian, analysis of Athenian society. Democracy, with its egalitarian thrust and structural dependence on verbal persuasion in the assembly, was felt to be in harmony with the anthropological facts of the human condition: the necessity for cooperation, mutual respect, and the substitution of persuasion for force. ${ }^{16}$ The same general sentiments seem to underlie the call for panhellenic unity based on broadly conceived notions of kinship of ten associated with the Sophists. ${ }^{17}$ The importance of persuasion and the general celebration of human intelligence in anthropology validated the primary activity of the "Sophist" in the narrowest sense of the term, teaching rhetoric and political science to those who aspired to power in the democracy. ${ }^{18}$

The Sophists' egalitarian perspective and pragmatic analysis of the socialization process, education in the broadest sense of the term, of ten led to a marked disparagement of the claims of the aristocracy to inherited excellence. ${ }^{19}$ Moreover, the practical, utilitarian, and generally materialist assumptions underlying the anthropological analysis of human progress readily lent themselves to a relativist analysis of ethics based on enlightened self-interest or hedonistic calculus and, correspondingly, a distrust of absolutist values supported by traditional anthropomorphic religion. ${ }^{20}$ At the same time, traditional religious views

\footnotetext{
${ }^{16}$ Protagoras' whole "Great Speech" is specifically called forth in defense of the democratic practice of the Athenian assembly (Prot. $\left.319^{b} 5^{-d} 7\right)$. The fact that the author of the Prometheus Bound casts the enemy of human culture and technological advancement as a tyrant is in keeping with the general pro-democratic bias of the anthropological thinkers; cf. Democritos $D-K$ B 252.

${ }^{17}$ Gorgias $D-K$ B $8 \mathrm{a}$; Plato Prot. $337 \mathrm{C} 7-338 \mathrm{al}$.

${ }^{18}$ The Protagoras makes the clearest connection between the anthropology, in which politike tekhne $\bar{e}$ is presented as essential to survival $(322 \mathrm{~b} 6-7)$, and the actual content of the Sophist's teaching $\left(3183^{\mathrm{e}} 5-319 \mathrm{a}\right)$. Democritos' description of education as a means of building sōtêrie for one's possessions and life has an anthropological ring ( $D-K$ B 280).

${ }^{9}$ Democritos $D-K$ B $57,242,33$ (on this see Vlastos 1946: $55^{-56}$ ); Kritias $D-K$ B 9; Antiphon $D-K$ B 6 o. Protagoras $D-K$ B 3 seems moderate on this issue, but in Plato's dialogue the whole thrust of the Sophist's analysis of the socialization process is to demonstrate its priority over inherited characteristics. Moreover, like Democritos $D-K{ }_{\mathrm{B}}{ }_{5}^{6}$, $85,109,183$ ), he undercuts the special pride of aristocratic birth by using such terms as phusis, aphuess, and euphuēs to designate natural endowments that are not associated with descent from a particular family line but a matter of chance (e.g., 327b4-c3); see Adkins 1970: 94 .

${ }^{20}$ Democritos $D-K$ B 71, 74, 76, 172, 173, 188, $211,219,235,237$; Plato Prot. 334a3c6; Dissoi Logoi.
} 
and traditional values seem most of ten to have been reinterpreted and redefined rather than openly repudiated. ${ }^{21}$

The late fifth-century stereotype-later elaborated by Plato-of the Sophist as a self-seeking, double-talking relativist, a dangerous atheist committed to corrupting the minds of the young for exorbitant fees, may represent a logical, but not necessarily inevitable, development from the philosophical assumptions of the anthropologically oriented older Sophists. The impact of a long war on any sort of optimism and human kindness is surely a more relevant consideration than the usual cliches about the Sophists ruining Athens (Muir 1985: 191-93). In any case, as I hope my analysis demonstrates, Sophokles was not simply affected by that later development but also clearly grasped and was deeply impressed by the entire three-stage conception of human society and human values. Indeed, as I try to demonstrate, it is tempting to read Sophokles' play as a conscious juxtaposition of the humane vision of the older Sophists with the brutal instrumentalism of their late fif thcentury followers.

\section{Sophokles' Response: Transforming Anthropology into Drama}

Sophokles was a poet, a dramatist-not a philosopher, political scientist, or a pamphleteer. Insofar as sophistic thought is present in his work it is indirectly present in the form of broad homologies between philosophical arguments and dramatic representations. These are created through the fullest possible exploitation of the fundamental elements of Sophokles' chosen medium - through plot choice and construction; setting; imagery both verbal and visual; verbal sound effects; characterization through action, interaction, speech, silence, and even inarticulate sound. Too many discussions of this play seem based on the assumption that the sole intention of this poet's careful artistry was to entertain his audience with a good play, as though the meaning of "entertainment" and "good" drama for Sophokles' audience in 409 B.c. was self-explanatory and inherently nonpolitical. Thus innovations in the myth are, we are told, designed to create intrigue, heighten dramatic or ironic tensions, endow the plot with concentration, or simply

\footnotetext{
${ }^{21}$ On the general topic, see Guthrie HGP 3: chap. 9. On Democritos' use of religious language, see Vlastos 1945: 581-82. Prodicus does appear to have been a radical atheist; see Henrichs 1975: 107-15. Apropos of Protagoras' allegedly equivocal religious views, Dodds aptly quotes Diogenes of Oenoanda: "To say that you have no means of knowing whether gods exist amounts in practice to saying that you know they do not exist" (1973: 97).
} 
"make a good scene." ${ }^{22}$ Although I yield to no one in my admiration for Sophokles' mastery of his medium, and I concede readily that I have learned much from such discussions, intention conceived at so low a level seems to me worse than a fallacy. "Pure art" is a dubious concept at best for any period; it is a flagrant absurdity in dealing with the drama of fifth-century Athens. Ironically, it is only in the case of Sophokles that scholars have been tempted to claim that here was a poet who achieved a proper Parnassian distance from the intellectual, social, and political revolutions that absorbed his contemporaries. Indeed, it is worth asking whether the impression Sophokles gives of a Homeric remoteness from his own times is not itself one of his most successful ideological effects.

Adequate consideration of the text itself must include the poet's use of and departures from traditional material known to his audience. It must also include the connotations for a contemporary audience of the word- and image-clusters he uses. Such consideration in turn involves awareness of the social and political realities shared by the poet and his audience. Though Sophokles' relation to these realities is often far subtler than in the case of his fellow dramatists, it is no less genuine and profound.

\footnotetext{
${ }^{22} \mathrm{~T}$. Wilamowitz and his spiritual descendent Waldock are often taken to task for an approach directed purely at dramatic technique (e.g., on the former, see Schmidt 1973: $5^{1}$ n. 28). Yet too of ten their detractors really only berate them for daring to criticize Sophokles from that perspective. Schmidt devotes considerable space, and admittedly it is one of the more useful aspects of his dissertation, to demonstrating Sophokles' artistic mastery in the Philoktetes by comparative analysis of roughly paralleled or contrasted scenes in other plays by Sophokles. Schlesinger (1968), who like Shucard (1974: 133-38) is primarily concerned with "intrigue," is much indebted to Knox's 1964 analysis of the plot structure in terms of the relations among persuasion (peithō), force (bia), and deceit (dolos). Innovations in the plot or difficult actions are viewed as a means for the "dramatist to heighten the tension" (99) or "to bring into prominence the end of the plot focused on intrigue" (106). Gellie (1972) is perhaps most fully in the tradition of T. Wilamowitz and Waldock: "At this point the play badly needs an injection of new material for the principal characters to chew on. ... Whatever its weaknesses, the scene plays well" (142). Spira (1960), whose point of departure (12) is a defense of Sophokles specifically against $T$. Wilamowitz's denunciation of the deus ex machina, speaks on one level of the necessity of bringing in "a new theme (Motif) once the themes set forth in the exposition are exhausted (erschöpft)" (29). On another equally abstract level he emphasizes the "poet's interest in character-drawing" which explain Sophokles' willingness to bring the action to an "absurdity" (30) before resorting to the deus. Character drawing, like plots and intrigue, thus emerges as a self-explanatory interest; and the implications of the particular characters drawn for the realities facing Sophokles' audience are presumably as irrelevant as the implications of an image of life dominated by intrigue. However, pace Craik (1979), a representation of life dominated by radical, unanticipated reversals of fortune and by the machinations of subhumanly vicious people may say more about the actual life experience of the audience than an ahistorical quest for novelty on the part of late fifth-century tragedians.
} 
The broad outlines of the plot of the Philoktetes are clear in the brief allusion to Philoktetes in the catalogue of ships of the Iliad:

Those who had as their portion Mēthōnē and Thaumakiē

And held Meliboia and harsh Olizōn,

Over these Philoktes ruled, knowing well the bow-

Seven ships of them. Fifty rowers embarked in

Each, knowing well the bow for fighting by might.

But he lay on an island suffering mighty pains,

On very holy Lemnos, where the sons of the Achaeans left him,

Afficted with a bad wound from a destructive-minded water snake.

There he lay in agony. But soon the Argives beside their ships

Were about to remember Lord Philoktetes.

$$
\text { (Il. } 2.716-25)
$$

The Odyssey tells us that Philoktetes was among that happy few heroes who returned saf ely home from Troy (3.19o), and Odysseus boasts that at Troy "only Philoktetes surpassed me with the bow" (8.219-20). Proclus' summary of the Little Iliad fills in the tantalizing gap between the two Homeric poems, explaining how the abandoned, suffering hero became a pattern of final success: "Odysseus, after making an ambush, captures Helenos; and after the latter made a prophecy about the capture of Troy, Diomedes brings Philoktetes back from Lemnos" (Homeri Opera 5.106). From Diochrysostom (49 and 52) we find out about the lost tragedies of Aeschylus and Euripides on the subject. Aeschylus has Odysseus, not Diomedes, bring back Philoktetes, and Euripides, whose play is dated 431 B.c., combines the epic and Aeschylean versions by having both Odysseus and Diomedes bring him back.

To sketch broadly my argument in advance, I believe that Sophokles' two major innovations in the myth-first, the presentation of an uninhabited Lemnos, and second, the inclusion of Neoptolemos-reflect a conscious attempt to juxtapose dramatically the three stages of the sophistic analysis of society. ${ }^{23}$ The first stage is concentrated in the full presentation of Philoktetes' battle to survive on Lemnos in total isolation with the sole aid of his bow and the knowledge of fire making.

\footnotetext{
${ }^{23}$ Schlesinger with some justice presents the use of the deus ex machina at the end of the play as Sophokles' third major innovation (1968: 101-2). As should emerge clearly in the following discussion, Sophokles' use of Herakles grows organically from the poet's complex examination of and response to the Sophists' view of society. This "innovation" in my view is thus a direct if not inevitable consequence of the two logically prior innovations. But however one interprets the scene, or however drastically the scene affects one's understanding of the play, it remains a dramatic surprise at the very end of the play and takes up at most one twenty-fourth of the dramatic action. The desolation of Lemnos and the addition of Neoptolemos are introduced with heavy emphasis in the opening lines of the play and are dramatically relevant virtually every minute of the play.
} 
This stage grimly returns in the later part of the play when lyric laments evoke the imminent death of Philoktetes through starvation or from predatory beasts due to the absence of his bow. The second stage is dramatized in the bonds-both real and feigned-established between Philoktetes and, chiefly, Neoptolemos, but also, more ambivalently, the chorus. The third stage, the only one for which a relation to sophistic thought has received much critical attention, is focused in the figure of Odysseus and emerges in the educational relationship to Neoptolemos and in his role of spokesman for the state in his dealings with Philoktetes. ${ }^{24}$

Though the three stages of sophistic anthropology profoundly affect Sophokles' structuring and development of the traditional myth, he transforms the ideas of the Sophists in such a way as to offer his audience a passionate and highly personal affirmation of a reformed version of traditional aristocratic absolutism. Some critics who perceive at least some of the contemporary reference in this play conclude that the form itself is thereby diminished, that the Philoktetes is "a tragedy of less than complete seriousness" since "topicality of reference has little place in high tragedy" (Craik 1980: 247). ${ }^{25} \mathrm{~A}$ final answer to such a charge is perhaps precluded by the inevitable circularity of genre definitions: one deduces what the genre is from a specific, limited set of examples, then excludes from the genre instances that do not fit those deductions. On this basis, the Prometheus Bound with its burden of anthropological (Havelock 1957: 52-65) and political theory (Podlecki 1966a: 101-22) is not a tragedy, and of course our only surviving trilogy, the Oresteia, ends with a play marred by a happy ending. But the issue of how much and what kind of topicality was acceptable to a fif th-century audience is a legitimate one. Phrynikhos, the tragedian who was fined

\footnotetext{
${ }^{24}$ Segal (1981), as noted earlier, does deal extensively with the role of the Sophists' thought in the Philokietes. Though there is much I admire in his two long chapters on the play, I do find myself at odds with the general aura of depoliticized spirituality in which he casts the issues.

${ }^{25}$ I believe that Craik fundamentally misinterprets the issue of comic moments in the play by ignoring the complex class role of comedy in fifth-century Greece. It is inadequate, for example, to argue that, because Herakles - the most prestigious of Greek Heroes for Homer and Pindar-is regularly mocked and debased in peasant-oriented comedy, the hero has therefore been decisively stripped of all grandeur and prestige: "The very appearance of the god would tend to raise a laugh" (Craik 1979: 26). If this were the case, Alexander's efforts some seventy-five years later to cloak himself in the aura of Herakles (Pollitt 1986: 20, 26, 38, 50-51) would be unintelligible. Rather, Herakles is clearly a major site of ideological struggle sought and challenged as a paradigm by contending classes. The very convention of satyr plays burlesquing the heroes of tragedy suggests that designating a hero as exclusively or primarily comic is questionable. In the case of Philoktetes, Craik can cite only one instance of a comic representation before Sophokles' play, but this does not deter her from concluding that "neither Odysseus nor Philoktetes was a high tragic figure" (1979: 25).
} 
for producing a play about the capture of Miletus (494 B.C.; Herodotus 6.21 ) Soon after the event, may well have reinforced the tendency to draw plots from the politically safer body of Mycenaean myth, a tendency already clear in the titles (e.g., Pentheus and Contest of Pelias) ascribed to Thespis by Suidas. But as Knox has argued, it was Aeschylus, the so-called father of tragedy, who consistently "impose[d] on this primitive material [Greek myth] the contemporary framework of the polis-still ruled by kings as in the saga but reminiscent in many suggestive details of the polis in which the audience lived" (1983: 6; see also Taplin on Phrynikos in Knox 1983: 36). Sophokles inherited and adhered to this fusion of the mythic and the contemporary. Given both the dangers of Athenian political life (ostracism and heavy fines are only the most obvious) and the almost constant wars in which Athens was engaged, the myth of Philoktetes-the abused hero who somehow must be reintegrated into the society that has abused him-might be said to have had an inherently contemporary appeal. The tantalizing hints of Diochrysostom about the versions of Aeschylus and Euripides make clear the heavily political appeal of the myth; and the date of Euripides' version, on the eve of the outbreak of war (431 B.C.), is especially suggestive ${ }^{26}$ But whether Sophokles' infusion of sophistic doctrine detracts from or deepens the appeal of the myth can only be answered by a detailed reading of the play itself.

\section{The Primitive Struggle for Survival}

The absence of human inhabitants on Sophokles' Lemnos (Ph. 2, $221)$ and even of seaports $(221,302)$ is a drastic innovation contradicting Homer, Aeschylus and Euripides, and the common knowledge of every member of the audience. ${ }^{27}$ The reasons usually offered seem in-

\footnotetext{
${ }^{26}$ Dio even refers to the political emphasis (to politikon, Or. 52.15, though the Loeb translator renders it as "urbanity"). In any case, his paraphrase of the prologue of Euripides' version in Or. 59 has Odysseus speak of "toiling on behalf of the common salvation and victory."

${ }^{27}$ See Jebb's commentary on verses 2 and 302 and intro xxx-xxxi. Obviously embarrassed by the innovation, he suggests, citing a scholiast, that Sophokles may have assumed that the size of the island would make it possible for Philoktetes to think it was uninhabited though in fact it was not. Nothing in the text supports this view, and the silence of both Neoptolemos and Odysseus about any other inhabitants strongly militates against it. Nonetheless Maguinness (1958) defends his proposed emendation of line $54^{6}$ (reading pedou for pedon, giving the new sense "off the same part of the land") on Jebb's literal-minded assumption that Sophokles could not possibly have implied that the island was unf requented by ships. Albert Henrichs has called my attention to ancient lexigraphical explanations of the epithet amikhthaloeis applied to Lemnos at Il. 24.753 as meaning a-limenos. Jebb on $\mathrm{Ph} . \mathbf{3 0 2}^{02}$ comments that the epithet was probably understood in antiquity as "inhospitable." Since serious debate over the precise meanings of rare and synonymous words began in the fifth-century among the Sophists (see Plato's malicious
} 
adequate. The isolation of the hero is seen primarily as contributing to the pathos of his situation and perhaps better justifying his extreme resentment against those who marooned him there. Others find a symbol for an alleged psychological flaw in the hero. Still others see merely an attempt by Sophokles to avoid by this daring device the infelicities in the dramatic presentations of his predecessors. The extraordinarily persistent focus on the physical setting is described as romantic coloring and perhaps even as compensation for the inadequacy of the plot. ${ }^{28}$ To be sure, any such element is overdetermined, but I suggest that Sophokles, in presenting Philoktetes' battle for survival in utter isolation from other human beings, is primarily offering an image of the human condition that derives ultimately from the Sophists' speculations about the conditions of human life in the primitive, presocial stage. The constantly recurring references in the play to beasts, cave dwelling, rocks, weather, the difficulties of obtaining food, the absence of all but the most primitive herbal medicine, and the pathos of isolation keep relentlessly before the audience the most basic conditions of the presocial struggle to survive.

The opening lines of the play do not merely identify the setting, they underline its total lack of human inhabitants with emphatic fullness: "This is the shore of a sea-girt land, / Lemnos, untrod on, uninhabited by mortals" ( $P h .1-2)$. Odysseus describes Philoktetes' rocky cave home in terms of two basic necessities of survival: protection against the extremes of weather (psukhei . . therei, 16-17) and supply of water (poton krēnaion, 21 ). Neoptolemos' examination reveals that the cave is empty, but his phrase assumes the cave's function as a human dwelling (kenèn oikēsin anthrōpōn dikha, 32); and Odysseus' next question focuses on the whole range of factors that would distinguish this cave as a human habitation (oud' endon oikopoios esti tis trophe , 32). Neoptolemos first finds evidence of the most primitive bedding, the impress on leaves, then more decisive evidence of human presence: crude technology (phlaurourgou tinos/tekhnèmat' andros) and materials for making fire (35-36). The only reasons Neoptolemos and Odysseus can imagine for his absence are either need for food (phorbess, 43) or relief of pain, and the latter suggests the most primitive medicine achieved by mental observation,

parody of Prodicus at Prot. 337a 1-c4), it is possible that Sophokles was aware of these views of the word in $\mathrm{Il}$. 24.753. But this takes us no nearer explaining away $\mathrm{Il}$. 7.467, 14.230 , or $21.4^{\circ}, 5^{8}, 79$, or for that matter the context of 24.753 , which clearly involves commercial activity on Lemnos.

${ }^{28}$ Pathos: Pohlenz 1954: 386; Kitto 1956: 115 ; Opstelten 1952: 107; Segal 1963: $3^{8-}$ 39; Mursurillo 1967: 122; Ronnet 1969: 239, 254. Psychological flaw: Feder 1963: 4041; Biggs 1966: 234; Gellie 1972: 145; Segal 1981: esp. 292. Avoidance of predecessors' infelicities: Jebb on line 2; Opstelten 1952: 107; Letters 1953: 273; Kitto 1961: 321 . Romantic coloring: Letters 1953: 273. Inadequacy of plot: Waldock 1966: 208. 
namely, "some pain-killing leaf" (44). Thus the prologue introduces Philoktetes in terms of the primitiveness of the conditions in which he must struggle to survive.

Despite what seems a dramatically adequate description of his cave home in the prologue, a primary focus of the ensuing dialogue between Neoptolemos and the chorus is the nature of Philoktetes' cave and the harsh conditions of his existence. Neoptolemos invites them to examine the place $(144-46)$; then they ask-with redundancy remarkable even for a Greek chorus-what his dwelling is like: "What sort of chamber [aulas] does he dwell in as a resident. ... What's his home [he$d r a]$ ?" (152-58). If one adds to this Neoptolemos' preceding reference to melathrōn (147) and his reply ("you see a home [oikon] that's a rocky place to sleep [koitēs], 159), one almost gets the bizarre idea that Sophokles was trying to offer a survey of all the possible Greek terms for dwelling! This is not, however, mere elegant variation; it functions as a means of giving the greatest possible emphasis to the harsh conditions of Philoktetes' struggle to survive-conditions explored in the lyric dialogue that follows $(160-176)$.

Neoptolemos repeats and expands Odysseus' earlier inference that Philoktetes' absence must result from his need for food (phorbēs khreia). The "essential character of his life" (biotès ... phusin) consists wholly in this quest for food through hunting wild beasts (therrobolounta), and his total isolation is imagistically focused in his lack of anyone to heal his ills (167-68). The chorus picks up and expands this grim evocation of Philoktetes' isolation. He is devoid of both human companionship and aid, he is "always alone" and is "at a loss in the face of each need [khreias] as it arises." The repetition of khreia so soon after phorbēs khreias reinforces the focus on the absolute necessities of survival. In this context the chorus asks the question that embodies a major dramatic interest in the first half of the play: "How in the world does the poor man endure?"

Most editors print $\bar{o}$ palamai theōn at line 177 , that is, a purely conventional exclamation at the mysterious devices of the gods. But if the manuscript reading of the next phrase ( $\bar{o}$ palamai thnētōn, "O the devices of mortals!") is correct, the words express the chorus's admiration for the human resourcefulness to which they attribute Philoktetes' survival. ${ }^{29}$ The chorus's ensuing lament $(180-190)$ focuses once more on Philoktetes as "unaccommodated man" (pantōn ammoros en biōi). His isolation is again stressed, but this time the idea is expanded on by the

\footnotetext{
${ }^{29} \mathrm{Jebb}$, Webster (1970), and Dawe (1985) all accept Lachmann's emendation theōn ("of the gods") for thnèton; but Jebb at least recognizes the true force of the manuscript reading: "O palamai thnètōn, if sound, would mean 'the resources of men' (as shown by Philoctetes) so Theognis 630. Cp. the praise of man as pantoporos [all-supplying] in Ant. $360 . "$
} 
contrast to his association with "dappled or shaggy beasts" and by further allusion to physical pain, hunger, and "incurable and uncared-for sorrows." ${ }^{\circ}$ Then, climactically, they imagine the babbling echo that is the only answer to his bitter cries. As Philoktetes himself is heard approaching, the chorus reverts to this image of a cry in pain which no one hears and denies specifically the pleasant pastoral associations isolation might have for a contemporary audience: he comes "not with a pipe song, like a shepherd pasturing in the fields" $(213-14) \cdot{ }^{31}$ At a time when Euripides, Aristophanes, and perhaps others were exploring the idea of a life of peaceful isolation from other human beings in the friendly company of beasts, Sophokles seems to have been at pains to emphasize the horrors of real, total isolation from human society. ${ }^{32}$

Philoktetes' passionate greeting to Neoptolemos and the chorus sustains this emphasis on the horrors of being alone, desolate, friendless, and miserable (monon, / erēmon hōde k'aphilon kakoumenon, 228-29). ${ }^{33}$ His allusion to his wild appearance (apégriōmenon, 226) recalls the chorus's evocation of his life among shaggy and dappled beasts $(184-85)$. His long subsequent narrative of his life on Lemnos (269-99) not only suggests the pathos of his awful isolation but also narrates in detail the process by which he has maintained his life in these forbidding circumstances. It thus answers in part the chorus's earlier rhetorical question, how could he endure?

Philoktetes focuses on the bare necessities of human survival. He was left by the Greeks in the protection of a cave with the crudest coverings

${ }^{30}$ See Page 1940: 39; accepted by Webster 1970, ad loc.

${ }^{31}$ See the suggestion of Dover that "even long before Theocritus a shepherd's life and music may have been proverbially idyllic and cheerful"; quoted by D. Robinson (1969: 39).

${ }^{32}$ The motif of escape, usually to some isolated spot, from an intolerable human situation by means of a fantasied transformation into a bird is a commonplace of tragedy, especially in Euripides: e.g., Hipp. 732-51, An. 861-865, Ion 796-99; cf. Sophokles frag. 476 (Pearson) and O.C. 1081-83. In the Helen passage, the imagery of escape as a bird is combined with an explicitly pastoral metaphor, "obeying the shepherd's pipe" (1484-85). Ion's long monody (Ion 82-183) goes farther. He evokes in sacral and distinctly asocial terms a happy life in relation to springs, groves, and birds-though the latter are to be sure partly viewed as a nuisance. Aristophanes' Birds, though it embraces far more than a quest for pastoral bliss, does certainly contain this element (see Whitman 1964: 168). On the other hand, such plays as Euripides' Cyclops and presumably Pherecrates' Agrioi (alluded to in Plato Prot. 327d) suggest the popularity of exploring discontent with "advanced" culture by juxtaposing it to its opposite. In particular, the type of the ferociously misanthropic recluse seems to have emerged in the last quarter of the fif th century (see Handley 1965 on Dyskolos 6 ). Sophokles here seems to take advantage in an original way of available contemporary responses.

33Schlesinger (1968: 150) points out that monos ("alone"), erēmos ("deserted"), and aphilos ("friendless") occur in all the extant tragedies of Sophokles, but in no other do they play as significant a role as in the Philoktetes. He might have added that nowhere else are these terms given so literal a force. 
and a small aid consisting of food (boras / epōphelēma smikron, 275) ${ }^{34}$ His greatest horror on awakening is the lack of human aid $(280-81)$. He ironically sums up his total helplessness in terms of his discovery (hêuriskon) in the course of an exhaustive search of an "abundant provision" (pollèn eumareian) of "suffering" (282-84). Almost immediately he recounts the literal discovery of the barest necessities of survival through the agency of his weapon, the decisive nature of which is emphasized by its personification: "What was expedient [ta sumphora] for the belly / This bow you see discovered [eksēuriske]" (287-88). After shelter and food, his next need is water and fire to protect him from the extremes of winter. Painfully he contrives (emékhanōmèn, 295) to win water and wood. Finally, his laborious achievement of fire is made the climactic item in his triumph over the most elemental forces of destruction:

Next, there would be no fire at hand.

But by striking stone on stone at long last

I'd make shine forth the hidden flame, which saves me always.

Truly, a livable chamber with fire besides

Provides me with everything-except escape from my disease.

(295-99)

The emphatic, alliterative play on ephèn' aphanton phōs ("I brought to light the lightless light") and the suggestive inclusiveness of the phrase ho kai me soizei m' aei ("which still saves me always"), the literal sense of which is explained further in puros metal pant' ekporizei ("with fire provides everything"), rhetorically give to fire a role in Philoktetes' survival that may appear disproportionate to its warmth-giving function or even its function in cooking, to which no direct allusion is made. But in the context of Sophokles' anthropological metaphor of the presocial struggle for survival, fire constitutes an almost inevitable climax.

The constant concentration in the opening three hundred lines of the play on the harsh absolutes of Philoktetes' mode of survival-his rocky cave, his isolation except for beasts and birds, which constitute his sole diet, his total dependence on his bow-recurs with a grimly altered emphasis in the last third of the play when he is deprived of his bow. Much of the audience's reaction to the callousness of the chorus in proposing to leave Philoktetes without his bow (833-38) and Odysseus' ironically accommodating release of him to "tread his Lemnos" (1054-

${ }^{34}$ The strong poetic emphasis of the unique coinage epōphelēma, a word type favored by the Sophists, is stressed by Long (1968: 98). He does not, however, recognize the distinctly anthropological associations of the -ophel- ("help") element in the context of a struggle to survive. 
6o) depends on a full acceptance of the bow as his only means of survival. It is explicitly in these terms that Philoktetes first describes Neoptolemos' act: "You have deprived me of my life [bion] by taking away my bow [toksa]. . . . Don't snatch from me my life [bion]" (931, 933). ${ }^{35}$ Twice earlier $\left(189,215^{-16}\right)$ the chorus has sympathetically imagined Philoktetes' agonized cries to surroundings devoid of human life. Now when he is again denied a human response (934), we hear him directly lament to the ever-present but isolating water, the rocky harshness of the land, the impossible companionship of wild beastsall in language that recalls the imagery of his successful struggle in the early section of the play:

$O$ watery havens and headlands, $O$ companionship

Of mountain beasts, $\mathrm{O}$ jagged, broken rocks,

To you-for I know none other to address-

To you, my usual companions, I raise my cries.

Initially, Philoktetes' lament centers on the human outrage perpetrated against him; the harsh environment is invoked merely as a witness. But when a second appeal to Neoptolemos again meets with silence, a second apostrophe to the physical environment becomes a meditation on the active hostility it will manifest against a man who is now stripped of defense (psilos) and by the same token without means for acquiring sustenance (trophēn) (951-53). His rocky home with its two openings is now the chamber in which he must wither away from starvation, or, as he considers more closely, fall victim to his own former victims. He focuses with relentless parallelism and alliteration on the primitive law of the jungle which it will soon be his lot to illustrate: ${ }^{36}$

I myself, alas,

By my death will furnish a feast for those on whom I fed,

And those I used to hunt will now hunt me:

Alas! I will pay by my death the blood price of their deaths.

$\left(95^{6-59)}\right.$

${ }^{35}$ D. Robinson (1969: 43-44) def ends the play on bion ("life") and bión ("bow") against Jebb, who denies its presence. For me the play is decisively confirmed by Philoktetes' later bitter allusion to Odysseus "brandishing in his hand the means of my wretched sustenance" (tan eman meleou trophēn, $1125^{-26}$ ). Henry (1974: 4) adds plausibly Ph. 1416-17 as a further pun.

${ }^{36}$ Rhusion (959), a word that occurs in Homer (Il. 11.674) to designate the rough-andready justice of seizing cattle in reprisal for stolen cattle, seems from its use in tragedy (e.g., Aeschylus Ag. 535; Supp. 728) to have retained connotations of direct retaliation unmediated by legal institutions. 
In the long formal lament (kommos) beginning at 1081, the transformation of the environment implicit in $95^{1-59}$ is evoked again and explored more fully. The cave's changes in temperature, so appealingly described by Odysseus (16-19), now appear in a more intensified aspect ("now hot, now icy cold," 1084) $\cdot{ }^{37}$ What was earlier a home is now a rock hollow that will witness his death. The birds and beasts, his former prey, are now free to move or rest at will (1092-94, 1146-55), while he is fixed in his cave (1149-50). The most marked contrast between the man and the beasts is with respect to food. A man without weapons has no hope of food (1090-91); nowhere can he seek sustenance (biota, 1 158); he must feed on air (1058). The beasts, once the threat of the human weapon is removed, will take their full vengeance on his corpse $\left(115^{6-57}\right)$. This reversal has been alluded to earlier, but now the pathetic helplessness of a human being in isolation is further heightened by the suggestion that the land itself feeds the beasts (cf. ouresibotas, 1 148) while unaccommodated man cannot enjoy any of the advantages of "life-giving earth" (biodōros aia, 1161$) \cdot{ }^{38}$

This broad contrast between the conditions of a barely successful human struggle to survive in the opening portion of the play and the prospect of total obliteration of a man by environmental forces in the latter section constitutes what I consider a strongly anthropological framework within which the drama is played out. The imagistic emphasis on beasts, food, shelter, weapons, medicine, and fire; the terminological focus on need, advantage, discovery, contrivance, supply, resourcefulness; the emotional evocations of loneliness, fear, anxiety, and pain-all echo the anthropological speculations of the Presocratics and Sophists about the circumstances of presocial human life.

\section{Arriving at the Social Compact}

The relationships that develop as the play unfolds between Philoktetes and Neoptolemos and between Philoktetes and the chorus are dramatically complicated by the deception to which Neoptolemos and the chorus are committed at the outset; it renders much of what they say of questionable sincerity. This deception is not extraneous to the

\footnotetext{
${ }^{37}$ Webster (1970) comments on line 16: "Odysseus describes the cave like a houseagent, implying that its desirability mitigated his cruelty (68)"; contra see Ronnet (1969: 259), who takes Odysseus' description as proof that "toute l'humanité possible" is employed in the accomplishment of his duty.

${ }^{3}{ }^{8}$ We may recall that the special point in Protagoras' myth of the puns on the names of Epimetheus (Afterthought) and Prometheus (Forethought) is the contrast between all other animals, who are perf ectly equipped by Epimetheus with the physical means to survive, and man, who is "naked, barefooted, homeless (literally 'bedless'), and weaponless," $3215^{-6 .}$
} 
sophistic matrix of the play; it is, as I illustrate later, an intrusion from the third or contemporary level of sophistic sociology into the second stage. The situation is further complicated by Sophokles' addition of clearly nonsophistic elements, which I also discuss later. Despite these complications, the major dramatic thrust and much of the emotional power of the interaction of these characters derive in no small measure from Sophokles' exploitation of the second stage of sophistic sociology. Against the background of Philoktetes' isolated struggle for minimal survival, human bonds are established on the basis of spontaneous pity for a suffering fellow human being, spontaneous affection between human beings of the same race and same language, and, at the highest level-when deception and force have been repudiated-sincere persuasion aimed at the best interest of one's friends. This level is achieved only by the emergence of fundamental agreement about ethical and religious values: what is just, what is holy, and what is pious. The ultimate goal of the compact established at this level remains the same as the goal of Philoktetes' isolated struggle: survival. ${ }^{39}$

We noted earlier the climactic role given Philoktetes' achievement of the "salvation-light" (phōs) of fire, which saves him always (297), and suggested that that emphasis reflects the anthropologists' sense of the decisive role of fire in human survival at the presocial level. But the most frequent occurrence of the verb söizein is in Philoktetes' appeals and his interlocutors' promises for salvation from the horrible isolation of primitive life on Lemnos. For Philoktetes this means a return to the society and kin ties of his home and father; for Neoptolemos, through most of the play, and for the chorus throughout the play, it means a return to the society of the Greek army at Troy and full participation in their common attempt to destroy Troy. Despite these differences over the best kind of salvation, the grounds for saving Philoktetes are consistently examined in terms of a sophistic analysis of human ties.

The chorus, "strangers in a strange land" (135), anticipate with some anxiety encountering a man they have every reason to expect will be full of suspicion $\left(13^{6}\right)$. Their leader alludes apprehensively to the coming of the "frightening traveler" (147). But as soon as they hear the account of his grim way of life, they are overcome with pity (oiktirō, 169); as they meditate on his mode of life (170-90), he becomes for

\footnotetext{
${ }^{39}$ Avery (1965: 296) includes a brief appendix demonstrating the importance of the theme of salvation but seems to have little idea what to do with his data. M. H. Jameson (1956: 224 n. 16) alludes to sōtēria ("safety," "salvation") as a contemporary political slogan. This is quite plausible in the context of more than twenty years of war with devastating Athenian losses. But neither Jameson nor Bieler (1951), from whom he gets the idea, notes the specifically sophistic character of the emphasis on sōteria in many of the contexts cited by Bieler, particularly those from Thucydides.
} 
them a frightening example of the fragility of the human condition (178-90) and specifically an awesome reversal of the social order (18086). Summing up the pains and anxieties of his life, they again pronounce him "pitiful" (oiktros, 186).

Neoptolemos, however, seems at first to be made of sterner stuff; to the chorus's meditation on human suffering he opposes the brisk certainty of a divine plan (191-200). ${ }^{\circ}$ But whether disposed to distrust, sympathy, or cold indifference, the chorus and Neoptolemos in particular must be shaken by the dramatically unexpected outpouring of affection from Philoktetes on his arrival. ${ }^{41}$ Over and over again he expresses the affection (philia) inspired by all the factors that create a bond between them: their Greek dress is "most beloved" (prosphilestatē, 224); their Greek speech is "dearest utterance" (philtaton phōnèma, 234); the very wind that brought them together is "dearest" (philtatos, 237); Neoptolemos' father is "dearest" (philtatos, 242) and his homeland is "dear" (philē, 242). Philoktetes appeals immediately for pity on the simple grounds of his sheer misery and isolation: "Showing pity for a man wretched and alone,/ Suffering this way, isolated and friendless" (22728). When the chorus and Neoptolemos hesitate to reply, he begs them to speak on the grounds that is not eikos ("probable," "reasonable") for them not to speak to each other, implying that their humanity involves the reasonable probability of communication. ${ }^{42}$

After his full narrative of his abandonment by the Greeks and his long struggle to survive, Philoktetes prepares indirectly for his first appeal to be saved by describing the island and the behavior of the few previous chance arrivals. The island is not a place one chooses to visit for prof it (kerdos) or personal comfort (303). The few who have landed against their will have offered him only verbal pity (logois/ eleousi, 3078) since their pity (oiktirantes) extended only to the point of token gifts of food or clothing; they always balked at the fundamental service, the salvation of conveyance home (sōsai m' es oikous, 311 ).

\footnotetext{
$4^{\circ}$ Kitto (1956: $\left.111-12\right)$ is especially good on the defensive smugness of Neoptolemos' attempt to counter the chorus's expression of pity. His argument closely parallels Linforth's (1956: 107). See also Machin for an appreciation of the adroit way Sophokles prepares here for a later level of insight on Neoptolemos' part which would otherwise appear in harsh contradiction with his apparent level of ignorance in the prologue (1981: 63-69).

${ }^{4}$ This point is emphasized by Avery (1965: 280). The surprise derives in part from the contrast to Euripides' more obvious assumption that Philoktetes would be misanthropic and highly suspicious and would consider Greeks his worst enemies (see Dio. Chrys. Or. 59.6-7). Philoktetes' capacity, nicely stressed by Biggs (1966: 231), for a warm response to fellow human beings in spite of all he has suffered is the best refutation of the common view (e.g., Gellie 1972: 153; Segal 1981: esp. 292) that Philoktetes is too psychologically warped to participate in society.

${ }^{4}$ See Guthrie HGP $3 \cdot 178-80$ on the Sophists' invention of and fascination with the argument from probability.
} 
The chorus, with a naivete-or cynicism - that is dramatically ironic, declare that they pity him (epoiktirein, 318 ) in equal measure (317) with those former arrivals. ${ }^{43}$ Neoptolemos, however, in pursuance of the deception, appears to ignore the hint and proceeds to lay the foundation for the only bond between himself and Philoktetes conceived of in the original scheme, a shared hatred of Odysseus and the Atreidai. ${ }^{44}$ But in the course of his lie, he is again conf ronted by Philoktetes' spontaneous expressions of shared love and sympathy. Neoptolemos mentions in passing his father's death only to be interrupted by Philoktetes' expression of deep distress both for the father and the son (337-38). Disconcerted perhaps, Neoptolemos dourly suggests that Philoktetes has enough troubles of his own "not to grieve at the suffering of his neighbor" (340). Despite his explicit denial, the generality of his declaration in this context invites a consideration of the bases for shared feelings between human beings in proximity (cf. Democritos $D-K$ B 293; Antiphon $D-K$ B 59 ).

The sympathetic response of Philoktetes, when Neoptolemos' whole narrative $\left(343^{-90}\right)$ and the chorus's supportive lyric $\left(39^{1-402)}\right.$ are over, leads unexpectedly to a further revelation of shared affections. Philoktetes asks about various heroes whom he would have expected to act as Neoptolemos' allies: Neoptolemos' cousin the greater Ajax (41 1), Philoktetes' "noble old friend" Nestor, Achilles' beloved Patroklos (433-34). In each case, Philoktetes expresses strong sympathy for the death or misfortune of Neoptolemos' natural allies among the Greeks. The reflections of Neoptolemos about the consequences of war (43537) may still in part represent his deceitful pose, but it is hard not to see as well a perception genuinely shared with Philoktetes about who the "good men" (tous khrestous, 437) are. Neoptolemos' farewell to Philoktetes, calculatedly brusque as it is, nonetheless expresses a corresponding concern that the gods bring him relief in the way "he himself wishes" (461-63). The dramatic irony of this casually uttered

\footnotetext{
${ }^{43}$ Many readers (e.g., Fuqua 1964: 105; Schmidt 1973: 79) assume that here the chorus is doing their calculating best to adhere to Neoptolemos' injunction to back him up in his lies $(148-49)$. The ambiguity of their responses, as in the case of Neoptolemos' real feelings, is a delicate interpretative problem throughout most of the play; it is perhaps pointless to offer dogmatic judgment where the poet has clearly created an atmosphere full of ambiguity. On the other hand, the poet gives us more data than is sometimes perceived. We have heard this chorus moved to a strong, extended expression of pity (1699o) by the mere sight of Philoktetes' dwelling when there can be no question of deceit. The direct exposure to Philoktetes' pathetic appearance and speech seem dramatically more than adequate to move this chorus of Papagenos to pity. But Gardiner rightly stresses the Odysseus-like cheap cynicism of much of their behavior (1987: 20-26; 22 on this scene).

${ }^{44} \mathrm{~K}$. Alt $(1961: 150)$ correctly notes the emphasis in this scene on a shared hatred but fails to distinguish between the bond of hatred prepared for by Odysseus (59-64) and the bonds of affection and pity that arise spontaneously and have consequences much contrary to Odysseus' intentions.
} 
phrase foreshadows the only viable basis on which the bond between these two friends can become functional, a sincere respect for the real interests of one's friend.

Philoktetes now makes a direct appeal for sōteria; the verb sōizein recurs like a leitmotif through his speech $\left(487,496,5^{\circ}\right)$. This appeal uses the formulas of traditional supplication, but these are transformed by the untraditional circumstances from which he pleads for rescue, namely, his isolated struggle to eke out a bare existence on Lemnos. As a suppliant (hiketes), he begins with the traditional appeal in the name of his addressee's parents. His rhetorical expansion of that appeal ("in the name of whatever is dear [prosphiles] to you at home," $469)$ echoes his own earlier outpouring of affection $(224,234,237$, 242) and by its generality almost invokes a principle of affection. His appeal is not the traditional one to be spared death on the battlefield, not for protection from some powerful human enemy, not even for a simple material boon; rather, he appeals first and foremost not to be left alone in the wretched conditions which he has endured: "Do not leave me alone [monon] like this—/ Destitute [erēmon], in the miserable circumstances you see here/ And those you have heard surround my daily life" $(470-72)$.

To support his appeal, Philoktetes enlists a whole array of traditional ethical terminology that particularly evokes the world of Homeric shame culture: "For those who are true sons of their fathers [gennaiois]/ what is shameful [to aiskhron] is hateful and what is good [to khrēston] is glorious" $\left(475^{-76}\right)$. If Neoptolemos leaves him behind he will acquire "ignoble disgrace" (oneidos ou kalon, 477), whereas, if Neoptolemos does as he has promised, he will win "the greatest prize of glory" (pleiston eukleias geras, 478). He calls for the heroic virtue of tolma ("daring," 475, 481) and associates proper ethical behavior with the aristocratic class term gennaios ("noble," characteristic of a legitimate son of a noble, 475). Yet the content of the daring, the nobility, and the glory he envisions is worlds away from either traditional heroic virtues or the values of the third stage or contemporary world of the Trojan War. As is clear to the audience, who have watched the scheme against Philoktetes arranged in the prologue, in the world of contemporary self-seeking struggles there is no glory associated with the daring or nobility involved in an act of kindness to a suffering fellow human being-especially when that kindness amounts to enduring the physical disgust occasioned by a festering wound. ${ }^{45}$ In-

\footnotetext{
45Note too the fine reputation Odysseus promises Neoptolemos for a day's shamelessness $(83-85)$, discussed below. I am indebted to Winnington-Ingram for reminding me of this clearly intentional parallel phrasing.
} 
deed, the poet seems to invite recognition of the pathetic disparity between the ethical assumptions of Philoktetes and those of the real world by the emphasis on heroic terminology. What Philoktetes presents as meritorious behavior is in fact a more private sort of behavior in which pity and friendship based on common humanity, rather than the expectation of public acclaim, must play the decisive role. And it is precisely this sophistic "calculation" of human interdependence in the face of a hostile and dangerous world that forms the climax of Philoktetes' appeal:

You save me! You pity me, seeing

That the state of everything is fearful for mortals,

Full of danger, that after joy must come its opposite.

One who stand free of pain must look out for disasters, And while he lives, then keep guard on his life-

In case it be totally ruined before he knows it.

Pity is highlighted in the chorus's response (oiktir, anax, $5^{07}$ ) but combined with a crude, third-stage variation of the idea of calculation of self-interest: it is profitable (kerdos, $5^{11}$ ) to help Philoktetes because he is the enemy of their alleged enemies, the Atreidai. Their expression of pity may appear genuine in view of their previous sympathy expressed in his absence; but in the context of the deceit they are helping to work against him, it is not without shabbiness. Yet their hypocrisy is as nothing compared to the smug snobbery of Neoptolemos, whose reply apes the aristocratic, heroic flavor of Philoktetes' untraditionally humane ethics. It would be "shameful" (aiskhra) for him to prove inferior to the chorus in taking pains in the interest (to kairion) of a stranger (525).

The apparent self lessness of this act is met by Philoktetes with an ecstatic expression of affection (philtaton [dearest]... hêdistos [sweetest] ... philoi [friends]) and a wish to be able to prove in action the affectionate bond they have inspired in him (hōs $m$ ' ethesthe prosphilē, 530-32). The embarrassing naivete of Philoktetes' openness to the bond of philia in this feigned social compact is immediately juxtaposed, with tremendous dramatic power, to a proud invitation to Neoptolemos to learn (matheis) of his own real daring (tlènai), the harsh schooling (proumathon) he has gradually gained under the necessity (anankei i) of the grim circumstances of his struggle to survive in his primitive nonhome (aoikon eisoikèsin, 533-38).

The conception of friendship as affectionate mutual service articulated in this scene is echoed several times $\left(557-5^{8}, 5^{8}, 5^{87}-88\right)$ in more cynical, third-stage terms during the scene with the disguised 
agent of Odysseus. ${ }^{46}$ The concept reemerges on an idealistic plane after the merchant departs, as Neoptolemos takes his first step toward gaining control of the bow. Neoptolemos phrases his request to handle the bow in the language of religious awe (proskusai... hosper theon, 657 ). Philoktetes treats the request as a welcome opportunity to demonstrate his commitment to the self-interest (hopoion an soi ksumfere genesetai) of his friend $\left(65^{8-59)}\right.$. When Neoptolemos displays some hesitation whether his request is themis, a word that nicely equivocates between religious sanction and proper human behavior, Philoktetes' grateful reply defines holiness (hosia), right action (themis), and human excellence (aretēe) in terms of an act of kindly service (euergetōn) to a friend, such as he thinks he is receiving from Neoptolemos and such as he himself had performed for Herakles in winning the bow (662-70). Thus the bow, which in the absolute battle for primitive survival had emerged as a symbol of the technology that separates man from beast, becomes here a symbol of the service to a suffering friend which is held up as the fundamental basis both for affection and for a shared ethics in a social compact. ${ }^{47}$

Neoptolemos also couches friendship in terms of mutual service, but he adds special emphasis on his own enlightened self-interest in this friendship:

I am not sorry that I met and took you as my friend:

For he who knows the art of making fair return for fair service

Must prove a friend worth more than any possession [ktêmatos].

$(671-73)$

The audience's knowledge of the intended crass exploitation of this "friend" by Neoptolemos inevitably sharpens the dramatic contrast between the two definitions of friendship. ${ }^{48}$ This impression would as

\footnotetext{
${ }^{46}$ Laurenti 1961: 46-47 emphasizes that the merchant and Odysseus "speak a different language" from that of Philoktetes; cf. Parlavanza-Friedrich 1969: 59.

${ }^{47}$ I disagree with Harsh's whole interpretation of the symbolism of the bow, and in particular with the notion that it is an objective and unchanging symbol. Part of the richness of the symbolism is precisely that it changes with the different stages of society envisioned in different scenes. Musurillo (1967: 121-22) is much better on the range of symbolic associations of the bow. Segal's pervasively religious emphasis emerges again in positing the bow's "broader meaning as a gift of the gods, immortal and bearer of a godgiven destiny" (1981: 299). It is true that the bow figures in a complex destiny inaccessible to ordinary human calculations, but the crucial emphasis is on Philoktetes' having earned it by his action.

${ }^{48}$ Webster assures us (1970, ad loc.) that "again the emotion is genuine: Neoptolemos feels a natural sympathy for Philoktetes as a like-minded hero." Similarly, Kirkwood describes the lines as heartf elt (1958: 6o). Reinhardt's comment apropos of an earlier passage seems to me to be valid here too: "Even the gnomic generalization is put in the service of the deceitful game" (1947: 179). Parlavanza-Friedrich (1969: $\left.5^{8}\right)$ speaks more
} 
well be reinforced for those who retain the echo of Odysseus' seductive argument that "seizing hold of victory is sweet possession" (hêd $\mathrm{e}$. . ktêma, 81). As so of ten in Sophokles, Neoptolemos' words turn out to be true in a sense he cannot envision at this point.

The smugness of Neoptolemos' false friendship is immediately juxtaposed to a further reminder of Philoktetes' long struggle to survive. The chorus at $676-729$, "the only proper stasimon of the play" as Jebb noted, sustains the harsh reality of Philoktetes' situation for ten years alone on Lemnos. Thus it holds up for the audience a touchstone against which to test both the second-stage values of pity and friendship and the more ruthlessly utilitarian values of the third stage. After insisting on the absolutely undeserved character of Philoktetes' sufferings by the negative paradigm of Ixion, the chorus repeat their earlier expression of awe at Philoktetes' capacity to endure, then narrow their focus to a further exploration of a central theme of the anthropologists' account of the presocial battle to survive, namely, the lack of an abundance of material resources (eumarei'... porou, 704-5); cf. the ironic use of eumareia at 284). In particular, the theme of food is developed in the second stage of social development. The chorus offers a sustained contrast between the pathetically haphazard food and drink (i.e., game and standing water) of an isolated individual and the food and drink (i.e., bread and wine) that are consequences of the organized work of civilization $(706-17) .49$

bluntly of Neoptolemos' repeated use of "platitudes." Calder (1971) insists that Neoptolemos is an unredeemed villain from beginning to end and is accordingly most harsh on the "naiveté of those victimized by Neoptolemos idolatry" (1959). His attempt to present the mythic tradition about Neoptolemos as uniformly black (168) is an important reminder, but it conveniently (for his argument) brackets Odysseus' speech to Achilles (Od. 11.505-37), in which, even allowing for Odysseus' tactful suppressions, Neoptolemos figures as the very embodiment of the successful son of a great father. Sophokles is clearly inviting his audience to meditate on both aspects of the character. At the same time that the smugness of tone in this immediate context deserves to be stressed, it is also true that in the broader context the lines reflect the clear dramatic irony that characterizes much of this section of the play; the terms of the deceit are in fact the terms on which real friendship will at last be established. Neoptolemos will reject the hêdu ktêma ("sweet possession") of victory offered by Odysseus (81) for the friendship of one ready to risk his life for the man who has saved his life (see 1404-8 and my subsequent discussion).

${ }^{49}$ Albert Henrichs has called my attention to the excellent, nearly contemporary parallel in Teiresias' "Prodicean" discourse on Demeter and Dionysos (Euripides Ba. 27485, with Dodds's note). See also Diodorus 1.8.6-8; Ancient Medicine 3.7, 13; Lucretius 5.944-45 and Cole's discussion ( $1967: 36-38)$. The emphasis in the Philoktetes on hunting alone rather than on gathering fruits and nuts represents, I believe, Sophokles' concentration of dramatic interest on the bow. At the same time, there is perhaps also an element of class ideology at work. For all his wretchedness, Philoktetes remains exclusively an aristocratic hunter; food gathering might associate him too closely with peasant farmers. 
For the chorus there seems to be no sense of conflict between their expression of pity for Philoktetes and the personal advantage they expect to win from him without his consent through their elaborate lies. ${ }^{50}$ Neoptolemos, though he appears earlier to be even more smugly confident in the pursuit of his own advantage, now begins to break down in the face of a direct experience of Philoktetes' hideous suffering from a sudden attack of his disease.${ }^{51}$ One of the fundamental ironies built into Sophokles' plot consists in the fact that it is precisely the direct experience of Philoktetes' hideous scream of pain-the reason alleged by the rest of the Greeks for abandoning him-that precludes Neoptolemos' abandoning him. ${ }^{52}$ It sweeps away his narrowly self ish defenses against the genuine pity and affection he has begun to feel for Philoktetes. Thus conditions for a genuine social compact between

\footnotetext{
${ }^{5}$ Reinhardt's attempt (1947: 191) to defend the chorus by distinguishing a double function (supporting the intrigue, stressing the sufferings of Philoktetes) pinpoints a problem rather than solves it. He is followed closely by Burton (1980: 226-50). Linforth's attempt to exonerate the chorus (1956: 127-30) and in particular his argument that they only express Neoptolemos' suppressed sympathies (cf. Schlesinger 1968: 138) gives us a curious sort of psychodrama that obscures Sophokles' sharp sense of a class difference between the perceptions and emotions of the chorus and those of the son of Achilles (see Gardiner 1987: 48-49).

${ }^{51}$ In general I agree with Erbse's impressive refutation (1966: 189-9o) of attempts such as those of K. Alt (1961) and Schmidt (1973) to find mitigating hints of Neoptolemos' pity as early as possible in the play. Winnington-Ingram has stressed to me the implications of the repetition of palai $(806,906,966)$ in Neoptolemos' expression of pity and shame. Seale too speaks persuasively of "sustained ambiguity which forms the basis of the dramatic tension, allowing two possible interpretations of the behavior of Neoptolemos and the Chorus, deception or sincerity" (1972: 98). Of course, a good actor playing the part of Neoptolemos would attempt to exploit this dramatic possibility to the hilt, and it is equally true that Neoptolemos' conversion must be dramatically credible. At the same time, def enders of Neoptolemos tend, in my view, to take inadequate account of the far more impressive dramatic tension between, on the one hand, the shabbiness and narrow selfishness of Neoptolemos' conversion to Odysseus' goals and means in the prologue and, on the other hand, the terrible misery, amazing inner strength, and decency of the victim constantly before our eyes to whom Neoptolemos keeps lying so long and so effectively. Whatever hints of distress might be conveyed by gesture and however much ambiguity the initial conflict of values with Odysseus in the prologue may lend to Neoptolemos' situation, the actual content of his words and behavior toward the helpless and trusting Philoktetes remain morally shocking until the attack of the disease finally breaks down his defenses. Grene puts it well: "It is surely remarkable how very sharply Sophokles has chosen to mark the limits of Neoptolemos' decency. ... He takes a very long time to come to himself, to realize that he cannot win his objective at such a price of torturing another human being" (1967: 145).

${ }^{52} \mathrm{Knox}(1964: 130-31)$ has a powerful discussion of this scream, yet his own irony blurs the dramatic irony in the play; he declares, "We understand now fully why the Achaeans abandoned him" (131). Ronnet (1969: 256) even def ends as valid the "religious scruple" alleged for abandoning Philoktetes. Craik's attempt (1979: 28) to find "an element of burlesque" in this scene strikes me as grotesque. Gardiner (1987:37) is especially good on the way the text, with its "frantic antilabe, the stumbling meter," the explicit question from Philoktetes, "Why are you silent?" (805), clearly marks Neoptolemos' deep reaction to the horror of human pain.
} 
them begin to emerge. Philoktetes' agonized cry for pity (oiktire me, 756) and Neoptolemos' own inability to help him (757) elicit from Neoptolemos a highly emotional, heavily alliterative lament: "Alas! Alas! You poor man!/ Truly, poor man you clearly appear through all your pains!" (iō iō dustēne sul Dustēne dèta dia ponōn pantōn phaneis, 7596o). His own long-suppressed pain at the pain of his friend is soon expressed openly in terms that echo, with great dramatic irony, his own earlier injunction to Philoktetes not to "groan at the pains of his neighbor" (340): "I have long been in pain, groaning at your sufferings" (8o6).

Philoktetes now swoons into unconsciousness, after entrusting his bow to his friend with a strong affirmation of their mutual dependence (772-73) and exacting a pledge (pistin, 813) that Neoptolemos will stay. The split between the chorus and Neoptolemos at this point emerges sharply. He ref uses to accept their broad hints that he take the bow and leave the man. ${ }^{53}$ Yet at this point there is only a hint that his motives involve a fundamental agreement with Philoktetes about ethical values; he echoes emphatically Philoktetes' transformed moral terminology of the shame culture (aiskhron oneidos, $84^{2}$, cf. $476-77$ ). ${ }^{54}$ The chorus perceive only a simple choice between something that involves fear (phobōn, 864) and pain (pathē, 854) on the one hand, and, on the other, an opportunity for their advantage (kairos, 837; kairia, 863). Philoktetes' ecstatic praise of Neoptolemos on regaining consciousness sharpens further the conflict of values. For Philoktetes, the fact that Neoptolemos has remained transforms the light he now sees again into a symbolic victory light (phengos), confirming, beyond expectation, the bond between them based on a new kind of heroic endurance (tlènai) that in turn consists of pity (eleinōs) and cooperation help (ksunōphelounta moi, 867-71).

${ }^{53}$ Hinds $\left(1967: 175^{-76}\right)$, though excessively tentative, correctly refutes Linforth's (1956) absurd def ense of the chorus on the grounds that they do not explicitly say, "Take the bow and leave the man." There are good reasons for being vague when one makes so cruel a suggestion. Gardiner $(1987: 38)$ rightly points to the chorus being the first to introduce the idea that the bow is worth having without the man so that it is less of a shock when Odysseus takes it up subsequently. D. M. Jones (1949: $83-84$ ) nicely reminds us that Hera fetches Hypnos from Lemnos (Il. 14.230-31) to aid her seduction of Zeus. He suggests plausibly that in their hymn to Hypnos $(827-32)$ the chorus have in mind the ambiguity of his role as both bringing relief from pain and rendering his victims helpless and vulnerable to trickery.

${ }^{54}$ Winningham-Ingram (1969: 49) offers the attractive suggestion that Neoptolemos' use of hexameters here suggests not the sudden insight of an oracle (Bowra 1965: 281) but heroic action. "There is a discord between the Homeric metre and the unheroic enterprise in which the son of Achilles has allowed himself to be engaged." This view does not, I think, conflict with my argument that the context of Philoktetes' unusual predicament and his entire interaction with Neoptolemos substantially have altered the moral content of these shame culture terms. 
In Neoptolemos' ensuing painful confession of fraud, in the dramatization of his gradually completed alienation from Odysseus and his achievement of a full compact with Philoktetes, the decisive factors are pity, cooperative help, and a deeply transformed heroic ethic. Neoptolemos at first insists that his real intention in taking Philoktetes to Troy still includes the humane motive of saving him (sōsai, 918). But when Philoktetes demands back the bow, which is his only means of survival on Lemnos, Neoptolemos refuses on the grounds that obedience to the army involves a harmony of proper behavior (to endikon) and private advantage (to sumpheron, 926). A scathing denunciation by Philoktetes and his pathetic lament, evoking the death he must suffer without his bow, force Neoptolemos to acknowledge the terrifying pity (oiktos deinos) that has "attacked" him $\left(9^{6} 5^{-66}\right)$.

Throughout this exchange, a noteworthy series of verbal echoes highlights the fact that for Neoptolemos, locked into the crass calculations and manipulations that characterize "advanced" society, spontaneous feelings of pity and decency occasion an inner agony (8o6, 9o6, $913)$, a terrifying attack $\left(9_{65}\right)$, a sense of inner disgust (902) that directly contrast with the physical agony (e.g., 283, 731-820) that attacks (699) Philoktetes and the physical disgust $(473,900)$ occasioned by his wound. This careful symbolism of a wound in Neoptolemos' psyche resulting from his association with a corrupted society suggests the need for some caution in too easy an acceptance of the popular interpretation of Philoktetes' wound as a symbol of the hero's alleged pathological incapacity to relate to society. ${ }^{55}$ On the contrary, the wound, like the rest of Philoktetes' appearance, functions as a particularly striking instance of Sophokles' characteristic fondness for contrasting appearances with reality. The handsome young prince, shining with confidence and promise, turns out to have the real wound deep within. It is the scruffy old cripple who, as we have noted, reverses all expectations by his generous outpouring of affection for human strangers, his readiness to trust and serve his new-found friends; he has all the social instincts and basic decency that can reasonably be expected of any human being. His wound represents one of those arbitrary, inexplicable impositions of forces external to and beyond human control-an

\footnotetext{
${ }^{55}$ See note 41 above. The view was first popularized in Wilson's famous essay The Wound and the Bow (1941 [1929]: 272-95). Biggs, despite excellent perceptions of the ways Philoktetes' disease is sharply differentiated from those of Ajax and Herakles, still speaks of "the poison of deep grief" and interprets the emphasis on the stench of the wound as symbolic of the hero's fostering of his own self-pity and hate which "makes association with the sufferer so difficult" (1966: 233). Schlesinger also cautiously sets forth a psychological explanation of the wound symbolism (1968: 154-55). Segal (1981: esp. 292), as noted earlier, repeats the notion so of ten that it takes on, for all his caution, the force of a de facto "tragic flaw."
} 
amoral ananke that is as much a given as the harshness of the physical environment unmediated by society. ${ }^{6}$ The consistent characterization of the wound itself as a beast involves a symbolic intensification of the hostile presocial world from which Philoktetes must wrest his survival. ${ }^{57}$ Only in this sense does it symbolize his need for society, but clearly not just any society. His afflictions, both general and specific, require a society characterized by decency and pity.

Neoptolemos' vulnerability to these essential social emotions of pity and moral shame now opens the possibility for genuine social bonds. Philoktetes immediately fastens onto the idea of pity (eleesson, 967) and links it, just as he had in his first appeal to be saved $(476-78)$, with the shame culture ethic (oneidos, 968). Neoptolemos now is morally paralyzed and can only exclaim in terms that echo Orestes' moral paralysis when confronted by his mother's breast (Ch. 899), "What am I to do?" (969), "What are we to do?" (974). But from the angry exclamation of Odysseus, who now intervenes, Neoptolemos seems to have been in the process of returning the bow. After the intervention of Odysseus, pity seems something Philoktetes can only pray for from the gods (1042). But his desperation as Odysseus, Neoptolemos, and the chorus prepare to abandon him leads to a further appeal-first to Neoptolemos, then, when he fails to respond, to the chorus, whom he can no longer consider friends: "O strangers [ksenoi], will I really be left behind-desolate like this - / By you as well, and will you show me no pity?" (1070$71)$. Their reply affirms once more (see 139-43, 963-64) their total dependence on the judgment of Neoptolemos. Once again the pity felt and acted on by Neoptolemos plays a decisive role in the unfolding of the drama: he orders his men to remain with Philoktetes in the hope he will change his mind but comments: "True, I will have it said of me that my nature is full of pity/ - Said by this man, but all the same, stay" (1074-75). His assumption that this act of pity will win him a bad reputation (akousomai) in the eyes of Odysseus contrasts ironically with Philoktetes' earlier, apparently naive assumption that a failure in pity would bring Neoptolemos reproach in the eyes of mankind (brotois oneidos, 968).

In the ensuing lyric dialogue between Philoktetes and the chorus, the themes of friendship and pity are set in sharp relief against the full,

\footnotetext{
${ }^{56}$ Of itself, belief in necessity implies neither an archaic, demonic view of the world nor an anthropological view. But Biggs (1966: 233) rightly notes that, although Philoktetes can speak in generally pessimistic terms of the gods (e.g., 452), he does not, in contrast to Ajax and Herakles, attribute his wound to divine persecution or punishment. Only Neoptolemos raises such a moral/religious interpretation of the wound. In Neoptolemos' later allusion to a vaguely divine source of Philoktetes' sufferings (1316-17) the emphatic tukhas ("chances") precludes a moral view.

57This symbolism is beautifully worked out in Kamerbeek 1948.
} 
grim evocation of Philoktetes' inability to survive on Lemnos without his bow; the apparent breakdown of the social compact leaves him no longer able to confront successfully the presocial conditions of existence. The chorus chide him for rejecting their affectionate feeling for him (philotêt', 1121 ); they declare that they draw near him with complete concern for his best interest (eunoiai pasai pelatan, 1164) and describe the doom awaiting him on Lemnos as pitiful (oiktra, 1167). Yet they deny that they have had any part in a deception (dolos, 1117) of Philoktetes, reject any criticism of Odysseus (1140-45), and twice express their great eagerness to leave Philoktetes to his fate $(1177-81$, $1218) .5^{8}$ Indeed, the idiom they first choose to express this eagerness (phila moi, phila, 1 1 77) seems to embody the poet's ironic comment on the superficiality of their philotēs (bond of affection) for Philoktetes.

The consequence of the delay won by Neoptolemos' pity is course not the submission of Philoktetes but the completion of Neoptolemos' break with Odysseus. In the staccato exchange between the returning Neoptolemos and the unsuccessfully obstructive Odysseus, Neoptolemos describes his earlier behavior as a crime (hos' eksêmarton, 1224, cf. 1248) involving shameful deceptions (apataisin aiskhrais . . kai dolois, 1228, cf. 1233, 1249) and contrary to right (dikei i, 1233). He declares his imperviousness to fear (1251), even of the entire army (1243), as long as he is allied with "what is right" (töidikaioi $i, 1251)$. This passage is not uncommonly cited as marking a definitive repudiation of sophistic thought. ${ }^{59}$ It does clearly mark a particularly selfconscious internalization of the heroic shame ethic: terms that normally derive their validity from the approval or disapproval of the group are here held up as a basis for def ying the group's opinion. The attempt to found a more inner-directed morality based on traditional terminology is generally associated with the name of Sokrates, who in turn is presented by Plato as the very antithesis of a Sophist. Yet the process, never complete, by which the traditional shame culture's ethical terminology was transformed into a set of mental constructs affecting the psyche of an individual apart from witnesses was longer and

${ }^{8} \mathrm{~T}$ Twice, that is, if the much suspected (see Jebb, ad loc.) lines $1218-21$ are retained. Taplin (1971: 39-44) has renewed the attack on them. It is hard to say how much his conviction of their inappropriateness is affected by his false view that the chorus's attempt at persuasion has been honest $\left(3^{8}\right)$. Gardiner $(1987: 42-44)$ is particularly good on this "dialogue of the deaf" (44) in which she sees a "genuine attempt on the part of the chorus to persuade Philoctetes, an attempt which Sophocles deliberately designed to fail, in order that we may see Philoctetes' refusal to go to Troy as a natural consequence of the brutal treatment he has received, rather than as merely petulant obstinacy.... The chorus seem to be engaged not so much in persuasion as in recrimination" (42).

${ }^{59}$ E.g., Knox 1964: 136 and Pohlenz 1954: 335. Opstelten (1952: 108-9), though he does not specifically cite this passage, seems to have it particularly in mind. Again, Nestle (1910: 155) seems to have set the pattern. 
more complex than Plato suggests. We have already seen how central such an internalization of values is to Aeschylus' vision of democracy. The anthropologically oriented thinkers who explored the origin of ethics in the survival needs of the group also examined the subtle socialization process by which necessary values are internalized in members of the group. They recognized that without some internalization of ethical values no social intercourse is possible, that instead of relations based on persuasion there would be only deceit or brute force. ${ }^{60}$ Thus, despite the clear admixture in the ethical assumptions of the Philoktetes of nonsophistic or even antisophistic elements, the dramatization of the break between Neoptolemos and Odysseus is in harmony with significant aspects of the sophistic analysis of the social compact. The emergence of fundamental agreement about ethical matters between Neoptolemos and Philoktetes is presented as an integral factor in the establishment of bonds of true friendship and sincere pity, which in turn are the prerequisites for the survival and joint action of these two men.

The break with Odysseus is followed by the reestablishing of bonds of pity and friendship, based on a concern for the best interest of one's friend, presupposing fundamental agreement about ethics and directed toward the salvation of both. Thus, just as there were two views of the presocial battle to survive-one successful with the bow, the other impossible without the bow-so there is a double dramatization of the process of establishing the social compact-one perverted by the intrusion of deceit, the other purged of suspicion caused by previous deceit. In this second version there is an important difference of opinion between friends on a matter that affects the survival of each. Thus this scene dramatizes the problem of the grounds of persuasion, which is presented as a fundamental need if human beings are to survive in a group.

Neoptolemos begins by expressing his desire to persuade through speech (1278) and to speak pros kairon (1278), which in the context of his retention of the bow retains an ambiguity: does it mean "seasonably" to Philoktetes' advantage or does it retain Neoptolemos' earlier expressed commitment to the intentions of the Atreidai? Philoktetes at

\footnotetext{
${ }^{60}$ Adkins's chapters (1970: chaps. 4 and 5 ) on the Presocratics and Sophists are disappointing on this topic, due in part, I suspect, to his ignorance or disregard of Havelock's work. Adkins does not even discuss anthropological speculation until he deals with the Epicureans and deals only superficially with a few of the ethical fragments of Democritos (1970: 101, 107, 110). Guthrie too is deficient on this topic for similar reasons: he is unduly hesitant to take Democritos seriously (HGP 2.489-91). On Democritos, see Vlastos 1945 and 1946 . On the whole topic, see Havelock 1957: esp. chaps. 6-8. On the need for internalization of ethical values, particularly in a democracy, see Chapter 4 on fear (to deinon, deos) in the Eumenides.
} 
first rejects persuasion on the grounds that Neoptolemos' previous deception precludes genuine friendship, that is, friendship based on sincere concern for the friend's best interest (eunoun, 1281). ${ }^{61}$ But once Neoptolemos has returned the bow and restored to Philoktetes the means of minimal survival, spontaneous affection (o philtat' eipōn, 1290) begins to return. Once this bond is reestablished, Neoptolemos sets about the task of serious persuasion $\left(13^{1} 5^{-96}\right)$. He begins by setting forth quite abstractly the conditions under which human beings merit pity (epoiktirein, 1320), namely, when their sufferings are imposed and enduring them is inevitable (anankaion, 1317). Philoktetes, he argues, by refusing proffered social ties demonstrates the characteristics of a beast (ēgriosai, 1321). Bestiality is further defined as a refusal to accept joint decision making by failing to distinguish friend from enemy. The whole argument recalls sophistic attempts to define what is peculiarly human as a basis for exploring the foundations of human social bonds. ${ }^{62}$

After Neoptolemos has raised these general preliminaries to persuasion, he catalogues a series of concrete advantages that will accrue to Philoktetes if he returns to Troy. These include cure for his malady and winning supreme renown as the sacker of Troy. ${ }^{63}$ Philoktetes' agonized reply is first a wish that he were dead. The intensity with which he states his predicament suggests that he is by no means devoid of human susceptibility to the kindly intentioned (eunous) advice of a friend: "Ah me, what am I to do? How can I distrust speech/ Coming from this man, who has advised me with good will?" (1 $350-51) .{ }^{64}$ With-

${ }^{6}$ 'The theses of Knox (1964: 119-20) that Odysseus' choice of dolos ("deceit") over bia ("force") or peitho ("persuasion") precludes the success of peithō, which might have worked if it had been tried first, is taken up by Schlesinger, who adds a suggestive analysis (1968: 103-5) of the embassy in $\mathrm{Il}$. 9 as a parallel and a usef ul discussion of the ambiguity of persuasion in Gorgias (123). The thesis is attractive insofar as it casts light on the meanness of Odysseus' assumptions and reminds us of the very solid grounds for Philoktetes' distrust, but Schlesinger in particular tends to argue the matter as if the primary intention of Sophokles were to display his cleverness in writing a drama of intrigue.

${ }^{62}$ The gist of Neoptolemos' argument has some affinities with Protagoras' analysis of faults that merit pity and those that are punished (Prot. $323 \mathrm{c} 8-324 \mathrm{Cl})$, the unusual character of which is well emphasized by Havelock (1957: 174) and Guthrie (HGP 3.67). For the beast analogy, see Democritos $D-K$ B $57,198,278$, and perhaps Antiphon $D-K$ B 48 .

${ }^{6}{ }_{3}$ Machin (1981:61-103) treats in great detail the dramatic mechanisms by which this information, which Neoptolemos seems to know now for the first time, emerges as just barely plausible from his lips in this context.

${ }^{64}$ Philoktetes' use of the virtual formula for climactic tragic helplessness at an impossible decision ("What should I do?" ti drasō, 1350, cf. Aeschylus Ch. 899) echoes Neoptolemos' earlier pained declarations of helplessness $(908,969,974)$ and dramatically underlines the intensity of his dilemma. This strong expression of Philoktetes' openness to genuinely friendly persuasion is undervalued by those who present Philoktetes as impiously stubborn or psychologically damaged by his hatred of his enemies (e.g., Bowra 1965: 293; Ronnet 1969: 255-58, Winnington-Ingram 1980: 296-97). To be open to the persuasion of friends is the mark of a true aristocrat (see Ajax 330), but to refuse-in the 
out denying the advantages cited by Neoptolemos, Philoktetes implies, through a series of passionate rhetorical questions, that the most elementary social intercourse (prosēgoros, $135^{2}$; ksunonta, 1356) is unthinkable with men who are not kindly intentioned, who have treated him as Odysseus and the Atreidai have. But he is not simply motivated by bitterness for past crimes; it is the strong probability, based on their previous and recent behavior, of equally unjust treatment in the future which seems to preclude social ties and joint action with such men $(1359-61) .{ }^{6}$ Philoktetes strikingly clinches his argument with what is in effect a sophistic argument from probability, but couched in language that fuses the metaphors of birth and education: ${ }^{66}$ "For men whose judgment/ Becomes the mother of evils, it teaches the rest evils" $(1360-61){ }^{67}$

Philoktetes now turns the tables on Neoptolemos. It is not to Neoptolemos' advantage to associate with such men, much less give them help (epōphelōn, 1371). Neoptolemos acknowledges the plausibility of Philoktetes' arguments but appeals simply for trust (pisteusanta, 1374) and reaffirms the bond of a friend (philou ... andros toude, 1375) ${ }^{68}$ Once more he declares his own belief that a return to Troy represents

face of the strongest inducements - to allow a criminal society to define one's role is the special characteristic of the Sophoklean hero; cf. Knox 1964: chaps. 1 and 2, esp. pages 8-9. K. Alt $(1961: 169)$ has a good appreciation of Philoktetes' vulnerability to Neoptolemos here: if he gave in at this point, it would be only out of friendship, not from hope of a cure.

${ }^{65}$ At line $68_{5}$ Jebb accepts Schultz's and Lachmann's isos ōn isois, for the reading of L, isōs en isois, and specifically denies that the text "implies that he dealt with isoi in one way and adikoi in another." Yet Philoktetes' argument at lines 1354-61 seems to imply precisely that familiar code; he cannot envision consorting with the Atreidai and Odysseus on the same terms as with Neoptolemos. Thus the reading of A rec, isos en isois, or Hermann's isos en $g$ ' isois (to correct the meter), only are not closer to L but more accurately describe Philoktetes' conception of fairness with a nice touch of dramatic irony: the chorus, like their political leaders, are not among the isoi and accordingly have no claim on Philoktetes.

${ }^{66}$ Cole (1967: 145-46) notes that the "the appeal to eikos [probability] was probably the most characteristic form of argumentation in the late fif th century, evident alike in drama, history, and oratory. ... What evidence we have suggests that the appeal to eikos was much less popular in the fourth century." To be sure, the word eikos is not used by Philoktetes here (note its earlier use by him at 230 and 498 and by Neoptolemos at 361 and 1373, with Winnington-Ingram's comment 1980: 296), but the gesture of predicting future behavior on the basis of past action, especially when cast in terms of education, has a sophistic flavor to it.

${ }^{6}$ Retaining kaka of the manuscript where Jebb reads kakous.

${ }^{68}$ Lesky (1972: 245) remarks on the artistically fine irony that it is Neoptolemos' own previous lies that render Philoktetes' arguments against participating in the Greek army even more plausible. Schlesinger (1968: 133) goes even farther, suggesting that the details of the lie Neoptolemos tells Philoktetes, inasmuch as they recall Agamemnon's theft of Achilles' prize of honor and Odysseus' def eat of Ajax in the judgment of the arms, turn out to be a poetic image of the real relationship of Neoptolemos to the Atreidai and Odysseus. 
the best interest of both Philoktetes and himself $\left(13^{81}\right)$. The issue of whose benefit (opheloumenos, MSS 1383; ophelos, 1384) sparks further debate and provokes from Neoptolemos a strikingly relativistic argument: the Atreidai, who have cast Philoktetes from society, will "save him back" into it (palin sōsous', 1391). ${ }^{69}$

When agreement on this sort of salvation seems impossible, Neoptolemos declares that he sees no alternative but to leave Philoktetes in his present circumstances, which he describes as "living" (zēnn), but living without the salvation of social supports (aneu sōtērias, 1396). Philoktetes now insists that Neoptolemos abide by his earlier dishonest promise to convey Philoktetes home. By his agreement now, however reluctant, the social compact of these two men is formally set in complete opposition to the third or contemporary stage of Greek society. It is this opposition that elicits the fullest mutuality in the bond between these two friends. When Neoptolemos asks how he will escape the attack of the Greeks, Philoktetes pledges his presence. Using a solemn polysyllable, a unique coinage that emphasizes the significance of the concept (Long 1968: 67), Neoptolemos asks "What act of helpfulness will you perform?" (tina prosōphelēsin erkseis, 1406). Philoktetes replies by pledging to hold off the Greeks with the arrows of Herakles. Thus the weapon Philoktetes had earlier defined in terms of mutual aid (66270 ) is confirmed in that function as the final basis of their compact. ${ }^{70}$

In the foregoing discussion of the relations of Philoktetes to the chorus and to Neoptolemos, I have featured several dominant, related themes: spontaneous affection and pity, concern for the best interest of

\footnotetext{
${ }^{6}$ Democritos $D-K$ B 172 and 173 are particularly suggestive of the peculiar delight in paradox characteristic of sophistic relativism.

${ }^{70}$ I cannot agree with those who, like Harsh, (1960: 408), Knox (1964: 139-40), K. Alt (1961: 172), and Segal (1981: 320), see Philoktetes' commitment here to defend his friend against the putative aggression of other Greeks as simply a misuse of the bow of Herakles. The bow has not been defined in this play in terms of civilizing service to Greece at large, but of special service of one friend to another. Nothing in Sophokles' play suggests that the destruction of Troy is inherently a service to the common goodindeed, the worth of the commonality as embodied in Odysseus and the Atreidai is much in question. Patriotic appeals are conspicuous by their absence here. This lack is particularly striking in view of the emphasis on patriotism in Euripides' version (Dio. Chrys. Or. 52.13, 59.1; ponein huper thès koinēs sōtêrias kai nikēs) presented at the outbreak of the war in 431 B.c. Since we are dealing with Euripides, however, there is a strong likelihood that these sentiments would emerge as heavily ironic if we had the whole play (see Webster 1967: 61). The date of Aeschylus' version is unknown, but it is hard to imagine an Aeschylean treatment of such a theme not being strongly patriotic. I do agree that the reference here to Herakles is one of several preparations for his later appearance; but his words consistently focus on the greater destiny awaiting Philoktetes and Neoptolemos. Troy is the proper arena for the exercise of Philoktetes' arete $\bar{e}$ and that in turn is seen as in accord with the slow-moving justice of Zeus; but the common good of Greece is not presented as a specific component of that justice but rather as the punishment of the guilty and the reward of the best $\left(14^{25-26)}\right.$.
} 
one's friends, the exploration of true persuasion, the process of arriving at agreement about ethical values. I believe that these themes, presented in constant juxtaposition to Philoktetes' isolated struggle to survive on Lemnos, constitute a dramatic exploration of the fundamental ties between human beings which reflects the anthropological speculations of the Sophists. Those speculations, as we noted, posit a presocial struggle to survive followed by a social-compact stage during which the achievement of human ties enables successful escape from the insecurity, isolation, and physical discomfort of the presocial stage.

\section{Contemporary Society: The Sophist's Way to Survive}

Though I have postponed full consideration of the many transformations by which Sophokles sets his own distinct ideological stamp on the sophistic matrix he employs in the Philoktetes, a few of the poet's changes are already obvious. We noted the decisive intrusion of the deceit from the contemporary sphere into the more naive and spontaneous interactions that characterize the bonds established between Philoktetes and Neoptolemos. Moreover, despite what I consider the dramatist's emphasis on the peculiarly sophistic bases of those ties, it is obvious that a bond between the two men against the whole world is radically different from the spirit of the older Sophists' view of a broad social compact based on common human needs. In Sophokles' version, the consolidation of the bond between Philoktetes and Neoptolemos before the entrance of Herakles seemed, as we noted, to imply irreconcilable alienation from Odysseus and more broadly from the Atreidai and the whole Greek army. Sophokles' sense of a gap and perhaps even of open hostility between, on the one hand, the social and ethical implications of the first two stages and, on the other, the contemporary world represented by Odysseus colors the entire dramatization of that contemporary world, giving it at times the air of a diatribe. Here in this isolated play, far more than in Aeschylean trilogy, tragedy seems to confront the audience directly with contradictions presented as irreconcilable (cf. Vernant and Vidal-Naquet 1988: 33; Segal 1981: $5^{1}$ ).

We come then to the point at which most discussions of the sophistic influence on the Philoktetes begin and end, the character of Odysseus and the educational implications of the addition of Neoptolemos to the traditional myth. ${ }^{71}$ As we noted earlier, the Sophists' interest in the

${ }^{71}$ E.g., Nestle 1910: 154-55, Weinstock 1937: 10o, Pohlenz 1954: 334-35, Lesky 1939: 370-73, Bengl 1942: 144-46, and Craik 1980. Ronnet (1969: 259-62) is the only work I have seen that undertakes to refute the association of Odysseus with the Sophists. 
presocial struggle to survive and in the bases for a social compact constituted a philosophical or pseudohistorical prop for their analysis and education in the technique of survival-of acquiring and exercising political power-in contemporary society, especially democratic Athens. Odysseus is unmistakably presented as a contemporary politician imbued with sophistic doctrines. He has distinctive ethical views and his own clear terminology of survival. In relation to Neoptolemos, he clearly enacts the role of teacher, and his difficulties in teaching are emphatically presented as a consequence of Neoptolemos' inherited nature, thus dramatizing a fundamental issue in the educational debate of the fifth century.

Odysseus' relation to Philoktetes, by which he functions in a large part as the spokesman of state authority, brings into sharp focus the sense of a potential conflict between the natural needs of the individual and the impositions of the community. This conflict, often loosely associated with all the Sophists under the tag phusis/nomos (nature vs. law or custom), probably became a central concern only toward the last quarter of the fif th century when its most radical implications were explored by the Sophist Antiphon. ${ }^{72}$ Thus we should note that even what appears to be the strongly antisophistic opposition in Sophokles' play between the first two societal stages and the third stage probably has its

Ronnet's main arguments are Odysseus' lack of eloquence and brusque reliance on threats and force in his one sustained encounter with Philoktetes $\left(974^{-1080}\right)$ and even in his interactions with Neoptolemos. She speaks instead of Odysseus' "laconisme" (261). This argument ignores the strong Athenian associations of his allusion to Athena Polias (134), but her emphasis on his relative lack of (flowery) eloquence, his open disparagement of long speeches $(1047-48)$, and his reliance on force and threats is valuable. It closely parallels the role of the Athenian spokesmen in the Melian dialogue, a passage in which, as far as I know, sophistic influence has never been doubted. In fact, Bowra $(1965: 286)$ cites this passage as an illustration of Odysseus' character. Moreover, a distinction must be made between eloquence, reserved as in Sophokles' other plays for the hero, and effective manipulation of arguments. In this skill Odysseus is quite impressive, as Knox (1964: 125) emphasizes.

${ }^{72}$ Fuqua $(1964: 55,70,215)$ maintains that this antithesis is the underlying organizational principle of the play. In the rather loose sense in which he uses the terms, I agree. He appears, however, unaware of the decisive role of anthropological speculation both in the formulation of the antitheses and in the structure of the play. In particular, despite a lengthy summary of the views of phusis set forth by Diller, Lesky, Heinimann, K. Alt, Muth, and others, there does not emerge from his argument a clear sense that the sophistic use of the term phusis grew directly out of an anthropological orientation that saw in the individual's basic physical and emotional needs a common core of fundamental similarity between all human beings and a link with other animals (see especially Antiphon $D-K$ B 44 ). As the scholars cited by Fuqua have noted, Sophokles' uses of the term are strongly aristocratic in flavor, emphasizing the moral factors that establish a rigid social hierarchy. Sophokles' juxtaposition of the needs of this aristocratic phusis to the impositions of organized society thus involves a virtual subversion of the egalitarian thrust of sophistic/anthropological phusis. It is just possible that Sophokles contributed as much to the assumptions of a Kallikles (see Plato's Gorgias) as did any Sophist. 
roots largely in the thought of more radical late fifth-century Sophists. ${ }^{73}$ Odysseus' ethical views and terminology of survival are consistently juxtaposed to those of Philoktetes and gain much of their pejorative or ironic color from the implicit contrast to the grimness of the reality or necessity that conditions Philoktetes' struggle to survive.

The chief means by which Odysseus expects to achieve success he calls at the outset of the play his sophisma ("trick," "piece of cleverness," or "sophistry," 14, compare sophisthènai, 77), which he himself redefines as "devising evils" (tekhnasthai kaka, 80). ${ }^{74}$ Neoptolemos immediately echoes this description by alluding to Odysseus' plan as acting from an evil devise or plan (ek tekhnēs prassein kakēs, 87 ). This pejorative sense of tekhne $\bar{e}$ as a deceitful contrivance is as old as Homer, but it has already gained special irony in the prologue by the contrast to Philoktetes, whose rough wooden cup is described as a "devise of some crude craftsman" (phlaurourgou tinos/ tekhnēmat' andros, 35-36). Similarly, Odysseus' Homeric aspect as the "man of many devices" (polumēkhanou andros, 1135) is given a particularly negative force, not only by its association in the immediate context with shameful deceits (1 1136$)$ but by the contrast to Philoktetes' more fundamental "contrivance" of the bare necessities of survival (emēkhanōmèn, 295).

Philoktetes' primary weapon in his physical struggle to survive is his bow. Odysseus' weapon in the battles of the contemporary world is his tongue:

Son of a noble father, I too once, when young,

Kept my tongue unemployed and my hand a hard worker.

Now that I've come to the test, I see that

The tongue, not action, has total sway over men.

Certainly the commitment to speech as opposed to the violence of weapons was a cardinal element in the more benign, pro-democratic sociology of the older Sophists. But Sophokles' characterization of Odysseus' commitment to speech clearly implies not progress but degeneracy; it is constantly associated with trickery (dolos, 91, 101, 102, 107, $608,948,1112,1117,1228,1282)$, deceit (apatē, 1136, 1128), and lying

\footnotetext{
${ }^{73}$ Moulton has argued persuasively for a closer relationship between Democritos' views of the potential conflicts between the individual and society and the views of Antiphon. He does conclude, however, that "Democritus was certainly more optimistic about nomos" (1974: 139). On the relative dates of the forms of the antithesis, see also Havelock 1957: 255-94 and Guthrie HGP 3: chap. 4.

${ }^{74}$ Craik 1980: $249-51$ is a useful historical survey of the change in soph-words from positive to negative connotations.
} 
(pseudos, 100, 108, 109, 842, 1342), not only in the view of others but often in Odysseus' own language. ${ }^{75}$ Indeed, his first description of Neoptolemos' goal, “to steal Philoktetes' soul [psukhēn] by speaking with speeches" (54-55), is closely paralleled by Gorgias' triumphant allusion to "speech which has persuaded and deceived the soul" (logos ho peisas kai tèn psukhēn apatēsas) $(D-K$ B $11=$ Praise of Helen 8). Although this "sophistic" aspect of Odysseus is frequently noted, scholars often ignore the fact that this aspect is counterpointed in the play to a full celebration of the triumph of sincere peitho over both verbal deceit and physical violence in the bonds of mutual support established between Neoptolemos and Philoktetes. Thus here too Sophokles seems to have exploited a contrast between the humane enlightenment implicit in the anthropological speculations of the older Sophists and the ferocity he perceived in the contemporary application of sophistic doctrines.

Ferocity is not too strong a term for Odysseus' behavior, since perhaps Sophokles' most pointed contrast between the contemporary and presocial struggles for survival is in his handling of the hunting motif. Not only is hunting constantly associated with Philoktetes' isolated struggle, but we recall that his bow is personified as "discovering the things needed for his belly" (gastri men ta sumphoral tokson tod' ekhēuriske, 288). Because Odysseus' weapon is his tongue, his "discoveries" are in fact nothing but the invention of ingenious lying arguments (hoia k' aksaneuriskeis legein, 991). ${ }^{76}$ His values, goals, and achievements are characterized as "hunting," fundamentally the hunting of human beings. The metaphor is first introduced to show dramatically Neoptolemos' decision to accept Odysseus' assessment of the situation: "If that is the case, it would appear they are worth hunting for" (theratea, 116). The verbal adjective is applied with heavy dramatic irony to the bow (toksa, 113) of Philoktetes, which Odysseus asserts is the only means by which Neoptolemos will be able to sack Troy.

It is not until the audience has been fully exposed to Philoktetes' literal hunting of birds and beasts with this same bow $(165,185,288-90)$ that the hunting metaphor is applied directly to Odysseus' characteristic behavior as a hunter of human beings. The alleged ship captain describes how tricky (dolios) Odysseus seized the noble son of Priam, Helenos, and displayed him in the midst of all the Greeks, a "fine

\footnotetext{
${ }^{75}$ Podlecki, though he begins his article (1966b) with a line from Gorgias, fails to set his survey of the allusions to speech and persuasion in the Philoktetes within the context of the fifth-century sophistic explorations of those ideas.

${ }^{76}$ Note the Hetton logos (the inf erior or worse argument) in Aristophanes' Clouds who boasts that he will gain victory over the kreitton logos (the stronger or better argument) "by inventing bizarre arguments" (gnōmas kainas ekseuriskōn, 896). Forms of heuriskō are, not surprisingly, common throughout the Clouds.
} 
catch" (thèran kalèn, 6og). Neoptolemos' first effective turning away from Odysseus' views echoes ironically his own earlier use of the metaphor (116) as well as the passage just quoted. Despite the urging of the chorus, he perceives that the bow alone without the man is a futile "catch" (thêran) for them (839-40). But it is reserved for the man himself, Philoktetes, to articulate the bitter reversals of nature involved in Odysseus' theft of his bow: not only will he, the hunter of beasts, become the hunted of beasts $\left(95^{6-58)}\right.$, but he has been reduced to this subhuman state as a result of being hunted (sunthèrōmenai, 1005; etherrasō, 1007) himself by a fellow human being who has used the unknown youth as his "hunting screen" (problèma, 10o8; see Jebb, ad loc.).

Sophokles further displays the anthropological character of the parallel activities of Odysseus and Philoktetes by summing up the goals of each with forms of the term sōteria. When Neoptolemos objects in the prologue to Odysseus' scheme on the grounds that it is shameful, Odysseus retorts that it is not if the lie achieves at least "being saved" (to sōthènai, 109). Having won Neoptolemos to his position, Odysseus leaves the stage at the end of the prologue with a prayer that encapsulates his guiding principles in the contemporary battle for survival: "May tricky Hermes be our guide and leader/ And Victory, and Athena-of-thepolis, who always saves me" (133-34). ${ }^{77}$ Odysseus defines himself in terms of deceit (dolios) and a commitment to victory (Nikē). For his safety he counts on Athena Polias, an epithet that implies broadly the supports of organized political life but also strongly suggests contemporary democratic Athens. This final phrase of Odysseus' credo (he sōizei $m$ ' aei) is later echoed in Philoktetes' equally climactic summation of his triumph over the primitive forces of the environment by making fire (ephēn' aphanton phōs, ho kai söizei m'aei, 297).

This sustained parallel between Odysseus' vocabulary for successful political manipulation and Philoktetes' description of his isolated struggle for minimal survival is one of the crucial factors unifying the intellectual matrix of the play. The inherent bitterness of the juxtaposition is made explicit again by Philoktetes. When he first realized the full import of the trick perpetrated against him, his outburst against Neoptolemos treats him as if he were Odysseus himself and strikingly combines the notions of fire, artifice, and deceit: "You fire! you total

\footnotetext{
${ }^{77}$ Calder declares: "The patron saint [Athena] was not to be contaminated by collaboration with oligarch [Odysseus]. Soph. Phil. 134 is a fourth century (?) interpolation, a doublet to 133, iriserted by an ignorant chauvinist, possibly to agree with Euripides' version" (1971: 169 n. 94). Though Calder claims the authority of Fraenkel, he offers no account of the echo of the phrase hè sōizei m' aei by Philoktetes at 297 (ho kai sōizei m' aei). Calder moves in a familiar circle when he expunges a line that does not jibe with his peculiar reading of the politics of the play.
} 
monster! you utterly hateful/ Contrivance of clever criminality! Look what you've done to me!/ How you've tricked me!" (927-29). Fire (pur), the symbol of his salvation through a literal technology of survival, is transformed here into the symbol of Philoktetes' destruction through the contrivance (tekhnema, 36) of a liar. The word "monster" (deima) may further suggest the bestiality that characterizes the behavior of "advanced" society toward "wild" Philoktetes. ${ }^{78}$

The contrast between the values of Odysseus and Philoktetes is, however, most sharply focused in their respective relations to Neoptolemos. This aspect of this much-studied play has been dealt with especially fully, but we can set that exploration of sophistic educational theory within the broader framework of sophistic anthropology and sociology. ${ }^{79}$ As we noted earlier, for the anthropologically oriented Sophists, their own activity as educators received philosophical validation in the fundamental role played by the learning process in the presocial battle to survive and by the educational process that inculcates the skills and ethical values essential for the preservation of the social compact. At the same time, their views and activities were deeply involved in the class conflicts of fifth-century Greece, particularly those of democratic Athens.

The relation of the Sophists to the class divisions of Athens is rather complex and explains in part the almost universally negative view preserved of their educational role: there was something about them to offend every class sooner or later. As we noted earlier, the general thrust of their anthropology was egalitarian, and most Sophists are associated with a pro-democratic perspective. ${ }^{80}$ Indeed, as Havelock has shown (1957), the fragments of their texts are the best single source from which to attempt to reconstruct the contours of democratic ideology. ${ }^{81}$ On the other hand, their large fees and foreign status precluded their serving the demos directly. Whatever their sentiments, they served the interests of those who had money, and accordingly they

\footnotetext{
${ }^{78} \mathrm{Jebb}$ cites a parallel (Aristophanes Lys. 1014) for the use of pur where therrion (wild beast) would correspond to deima here. See also Euripides Heracles Furens 70o, deimata thērōn, noted by Webster (1970, ad loc.).

${ }^{79}$ I find Erbse's 1966 article a most penetrating discussion, but he has nothing to say about the sophistic background.

${ }^{80} \mathrm{Kerferd}$ (1981a: 18-19) rightly emphasizes the patronage of Perikles, whose name is clearly associated with Damon, Anaxagoras, Hippodamos, Zeno, Protagoras, Herodotus, and, of course, Sophokles. The choice of Protagoras in 444 B.c. to compose the constitution for Perikles' pet project of the panhellenic colony at Thourioi, presumably intended to be a showcase for democracy, is particularly revealing.

${ }^{81}$ A. H. M. Jones's otherwise excellent chapter "The Athenian Democracy and Its Critics" (1964: 41-72) makes good use of the "Great Speech" of Protagoras in reconstructing democratic ideology, but it generally ignores the Sophists.
} 
seem to have been distrusted by the demos pretty early. ${ }^{82}$ Within the monied classes, their readiest pupils would appear to come from the newly rich, who were in a hurry to achieve political power in the democratic assembly and lacked the traditions of public life that characterized the older aristocratic families. ${ }^{83}$ To this bond with the newly rich we might reasonably attribute in part the tendency of several Sophists to downgrade or openly disparage inherited characteristics. We may reasonably attribute to the same cause the common hostility, first articulated by Pindar, of the born aristocrat to the activity of teaching and in particular teaching by Sophists. As I hope is clear by now, the qualities a Greek aristocrat claimed by birth were not primarily physical but moral and political, a point that is especially clear in the poetry of Pindar, whose genre invites emphasis on purely physical inherited superiority.

Still, the association of the Sophists with the non-aristocratic rich is sometimes exaggerated. Protagoras and Anaxagoras were closely associated with Perikles, whose lineage was second to none; and Plato's picture of the Sophists' clientele includes many scions of aristocratic families. The Sophists in fact seem to have been closely associated with what we might call the liberal wing of the ruling class, those who, regardless of their lineage, were open to employing the most up-to-date sentiments and methods-including professional education-to maintain or extend their power.

In the light of these divergent trends-on the one hand, sophistic education as a vehicle for the newly rich to achieve power and, on the other, sophistic education as an enlightened means of maintaining the status of the old ruling class-we should view Sophokles' second major innovation in the traditional plot of the Philoktetes myth, the inclusion of Neoptolemos. The emphasis on Neoptolemos' noble nature, inherited from his noble father Achilles-an emphasis no study of the play can ignore-is by no means incompatible with an important trend in sophistic educational theory. ${ }^{84}$ On the contrary, the use of stories

\footnotetext{
${ }^{82}$ See Guthrie HGP 3: 37-39. Whether Protagoras' book was ever burned (D.L. 9.52 = D.K. A 1 ) or Anaxagoras was ever in serious danger (Plutarch Per. $32.2=D . K . A_{17}$ ) is much disputed (see Kerferd 1981a: 43, 21-23; Muir 1985). But it does seem a reasonable inference from Aristophanes' Clouds that the demos had no love for Sophists.

${ }^{83}$ See Adkins 1970: 94. Connor, however, makes an interesting case for the antiintellectualism of many of the "new politicians" in the last quarter of the century (1971: 163-68). As our own era has taught us, anti-intellectualism is not at all incompatible with the use of intellectuals to help manipulate public opinion.

${ }^{84}$ Here I am most at odds with Diller (1936: 245-46) and Lesky (1939: 370-73). Although there is no explicit modification of his earlier view in a later edition of Dichtung (1972: 246), Lesky was far more definite in the earlier edition, which was translated into English (1965): as his final comment on the Philoktetes he cited Pindar Ol. 9.1 oo and concluded that "this world of thought is a complete contrast to that of the sophists and of
} 
about the offspring of famous noble heroes to illustrate educational doctrines seems a particular feature of sophistic teaching. Rather than attacking the pretensions of the aristocrats, they chose to set them in a new context that stressed the need for the noble phusis to be supplemented by paideia.

We know that the Sophist Hippias wrote a dialogue in which Nestor lays down the proper pursuits by which young Neoptolemos may show himself a "good [ruling-class] man" (agathos anēr, D-K 86 A 2.4). Prodicus' educational myth of Herakles' choice is especially suggestive of Sophokles' treatment of Neoptolemos. ${ }^{85}$ Baseness or Evil (Kakia) addresses Herakles first with words that perfectly sum up the dramatic interest of Neoptolemos in Sophokles' play: "I see, Herakles, that you are at a loss [aporounta] what path to turn to for your life." She then offers him the pleasantest (hëdistēn) and easiest path (D-K $84 \mathrm{~B} 2.23)$. Excellence or Goodness (Aretē) begins her subsequent appeal to Herakles by an emphatic allusion to his high ancestry and early upbringing: "I too have come to you, Herakles, knowing your parentage [tous gennēsantas se] and having observed the nature [phusin] that is yours through your education [en tēi paideiai]. On these grounds, I have hope ..." ( $D-K 8_{4}$ B 2.27). Prodicus implies no sharp Pindaric antithesis of education and inherited qualities $(\mathrm{Ol} .9 .100 ; \mathrm{Ne} .3 .41){ }^{86} \mathrm{He}$ grants and builds on the idea that noble parentage augurs well. But, true to his profession, he attributes the actual phusis of Herakles to his early education. This combination of high birth and the proper early rearing will, given the appropriate encouragement in early manhood by the right mature voice, achieve greatness. At the same time, the specific point of the myth is to emphasize the threat to the noble nature of the youth which is ready at hand in the appeals to short-term pleasures.

Those who see in Neoptolemos' final rejection of Odysseus a simple, old-fashioned affirmation of aristocratic phusis and an equally simple repudiation of sophistic educational theory ignore the structure and

Socrates" (126). Bengl (1942: 142) cites and echoes much the same view from an even earlier edition of Lesky.

${ }^{85}$ Ronnet goes out of her way to denounce a "Manichean" view of the play presenting "the two protagonists as Goodness and Evil between whom the young man hesitates" (1969: 258-59). Sophokles is, to be sure, subtler than Prodicus, whose young Herakles is offered a choice between discourses presented by the allegorical figures Kakia and Aretē $\left(D-K{ }_{4} \mathrm{~B} 1\right.$ and 2$)$. Yet the absolutism of the antithesis and of Sophokles' own moral judgment is parallel, as is the explicitly educational focus of Sophokles' version of the myth.

${ }^{86}$ To be sure, Pindar has kind words for the teaching of athletic trainers (e.g., Ol. 8. 54-61) and was perfectly aware that talent needed hard work and guidance. But this only makes his attack on "learned aretai" the more clearly ideological; he seems to imply that only those with the right ancestry can achieve authentic success-the rest is "mere" learning. 
dramatic development of the myth. Neoptolemos is on stage with Odysseus for a mere 134 lines, and in fact it takes only some 8o lines for Odysseus to lay out his plan and overcome Neoptolemos' objections by offering something hèdu (lit. "sweet," 81). After this brief "education" by Odysseus, Neoptolemos, despite Philoktetes' compliments to his parentage and early rearing $\left(24^{2-43}\right)$, despite his outpouring of affection and truly pitiful circumstances, displays consummate skill as a liar and hypocrite. He is on stage with Philoktetes an extraordinary amount of dramatic time, more than 1, ooo lines, before he is fully won over to Philoktetes' side.

The painfully slow process by which he moves from his initial callous readiness to use brute force (9o)-a revealing indication of the content, so to speak, of his untutored phusis-to a surrender of all the ambitions inevitable in such a youth is a primary dramatic interest of the play. There is nothing automatic or inevitable about the emergence of his good phusis. ${ }^{87}$ His rejection of the chorus's invitation to steal the bow and leave the man does force him to reveal the truth to Philoktetes; but, as we have seen, he still insists on following Odysseus' orders and insists on a basic harmony of his own narrow self-interest and what is right (926). When pity makes him waver, the mere appearance of his first mentor, Odysseus, seems adequate to suppress all but the most hesitant gesture of sympathy $(1074-80){ }^{88}$ Neoptolemos' return with the bow is definitely a calculated dramatic surprise, and even then he attempts persuasion before actually returning the bow (D. Robinson 1969: 45-51). Despite all the particularly Sophoklean emphasis on Neoptolemos' inherited nature, Sophokles has controlled the action in such a way as to dramatize the educational dictum of Antiphon: "One must necessarily become, with respect to character [tous tropous], of the same sort as the person with whom one spends the greatest part of the day" $\left(D-K{ }_{7} \mathrm{~B} 62\right) .{ }^{89}$ Sophokles in the Philoktetes is far nearer to Plato's

\footnotetext{
${ }^{87}$ Emphasized by Knox (1964: 122-23). Erbse (1966: 187) remarks that what Neoptolemos calls his phusis in the prologue is nothing more than a claim (Anspruch) which for a considerable part of the play he lacks the courage to validate. This seems an improvement over Diller's declaration that the real theme of the play is "the imperviousness of nature to external influences" (1936: 245). But the inadequacy even of Erbse's formulation is that it too accepts at face value the poet's verbal insistence on the emergence of Neoptolemos' noble phusis as if it were a fixed, unalterable entity while ignoring the full dramatization of a fundamentally different and richer content imparted to that phusis by good education-not to mention its vulnerability to bad education.

${ }^{88}$ Taplin (197 1: 35) nicely emphasizes the visual presentation of Neoptolemos' vulnerability to Odysseus' influence, who stops him in the very act of returning the bow and reduces him to silence for almost the whole rest of the scene.

${ }^{89}$ See also Democritos' emphasis on education by imitation and association ( $D-K$ B 154 , $39,79,184$ ) and Protagoras' similar focus on the consequences of association (Plato, Prot.

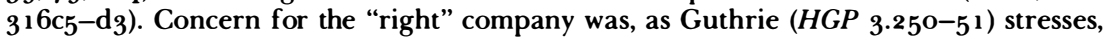


sense (particularly in the Republic) of profound anxiety for the fate of the well-born in the corrupting environment than to Pindar's confident affirmation that "thanks to birth the noble temper shines forth in sons from their fathers" (Py. 8.44-45). Like Plato and the Sophists, Sophokles dramatizes the absolute necessity of such a nature meeting with the right education.

But uniquely in Sophokles' play the conflict of the values between which the pupil, Neoptolemos, must choose is explored within the framework of learning to survive in three stages of the development of human society. Philoktetes has had to learn to acquiesce in sufferings imposed by necessity during his long struggle to eke out bare survival in isolation (538). In order to be saved out of that isolated struggle into a civilized human compact, both Philoktetes and Neoptolemos must, as we have seen, establish bonds based on pity, affection, and a sincere concern for each others' best interest. At this stage too they must agree on definitions of "daring," "noble," "right," "shameful," and "holy." The content, so to speak, of the good phusis which has been tested and educated in terms of this anthropological vision of reality emerges as more complex than could be inferred from Neoptolemos' initial commitment to truth, success, and violence.

The education Odysseus attempts to give Neoptolemos on survival in the contemporary world at times echoes these same terms, but in a strikingly different sense, and at times it directly repudiates them. Pity and affection are not in Odysseus' vocabulary. He occasionally takes a paternal tone, addressing Neoptolemos as son (pai, teknon), but words in phil- (i.e., "love," "dear") come not from his lips. ${ }^{90}$ We have no reason, given Odysseus' past and present treatment of Philoktetes, to believe that Neoptolemos is mistaken in assuming pity to be grounds for reproach from Odysseus (1074-75). Odysseus does attempt unsuccessfully to define the term "noble" (gennaion, $5^{1}$ ) in a self-consciously new (kainon, $\left.5^{2}\right)$ sense, but soon he frankly acknowledges that the inherited phusis (79-8o) of Neoptolemos is an obstacle. Later he expresses a fear that this very nobility (gennaios per on, 1068) may ruin everything. The situation with "daring" is a bit more complex because the idea itself is ambiguous and, depending on context, can imply heroic courage or behavior that flies in the face of public opinion. Odysseus urges Neoptolemos to be daring (tolma, 82) in the pursuit of victory $(81)$, which

also an aristocratic idea; but Guthrie underestimates the special emphasis of the Sophists on the decisive role of socialization in determining character.

${ }^{9}$ Avery $(1965: 285)$ counts two instances: teknon at 130 and pai from Neoptolemos' lie at 372 . He omits pai at 79 , an emendation, and those where the addition of a reference to his father $\left(5^{\circ}, 96\right)$ tempers the potentially affectionate tone. In contrast, Avery finds $5^{2}$ instances of the paternal address from Philoktetes. 
sounds a bit heroic, but the action is soon frankly described as shameless (anaides, 83, cf. Kirkwood 1958: 234-35 n. 23). Odysseus equivocates about the term for "right" (dikaios) behavior, now claiming it irrelevant for the present (82), later amplifying this relativism by the assertion that when circumstances require it he can be as devoted to right behavior as anyone (1049-51). But at one point, where the tone of his sophistry approaches broad comedy, he attempts a definition of "right" that would guarantee him the fruits of a theft on the grounds that he had planned it $(1246-47) \cdot{ }^{91}$ Holiness (eusebeia) he first presents a virtually synonymous with dikaios and, like that value, irrelevant in the present but available when the circumstances require $\left(85, \mathrm{cf} .10_{51}\right)$. The chorus, speaking of the arms of Achilles which the Atreidai allegedly gave Odysseus improperly, describe them as an "object of religious awe" (sebas, 402) for Odysseus. This suggests a pointed contrast to the religious awe $\left(6_{5} 6-62\right)$ that both Neoptolemos and Philoktetes express in relation to the bow of Herakles, there explicitly defined in terms of helping friends (euergetōn, 370). Odysseus later claims with great solemnity that his behavior is the will of Zeus $(989-90)$ and attempts to prevent Neoptolemos from returning the bow by calling the gods to witness (1293). Finally, when it comes to what is shameful, Odysseus is only mildly equivocal. In pointed contrast to Philoktetes, who asks Neoptolemos to endure less than one whole day of physical distress in return for the greatest prize of glory (pleiston eukleias geras) of saving a fellow human being (478-80), Odysseus asserts that if Neoptolemos gives himself over to Odysseus shamefully (eis anaides) for the short space of a day he will in the future have the reputation of being the most pious of all mortals $\left(8_{3}-85\right)$. But generally Odysseus characterizes himself and is characterized by others as completely indifferent to the shame ethic, precisely the terms on which the Athenians at Melos most sharply differentiate themselves from their traditionalist opponents.

The terms in which Odysseus first expresses that indifference strongly state what is also the primary basis on which his values and his behavior have been defended. ${ }^{92}$ He urges Neoptolemos, when he

${ }^{91}$ Lesky, without explicitly saying that the scene is comic, notes (1972: 244) the similarity to Old Comedy. Taplin (1971: $36-37$ ) goes farther and argues, rightly I believe, that both this scene and Odysseus' final exit are so close to the style of brief defeats of villains in Old Comedy that they dramatically confirm the impression of his baseness. As suggested earlier, however, these comic elements focused on the "low" character Odysseus do not justify Craik's attempt to treat the whole play as "a tragedy of less than complete seriousness" (1980: 247).

${ }^{9^{2}}$ This is most fully def ended in Ronnet 1969: 259-62, as noted earlier. See also Norwood 1948: 162: "It is easy but mistaken to label Odysseus the 'villain.' In reality he is the State personified." Yes, he is; but it is precisely in that role that he emerges as a villain. Muth's attempt to defend Odysseus on religious grounds (196o: $65^{2-56}$ ) is even less 
meets Philoktetes, to say of Odysseus the worst possible insults. With true sophistic bravado he casts the issue in terms of a hedonistic calculus (alguneis vs. lupēn): "You will hurt me not at all by this. But if you do/ Not do this, you will impose pain on all the Argives" (66-67). The chorus, in its lyric dialogue with Philoktetes when he has been stripped of his bow and abandoned, defends Odysseus in just these terms, namely, his service to the group as a whole (koinan). But here alone Odysseus' relation to the group echoes the theme of social bonds based on a tie of philia (cf. philous 1 143): "That man, one from many-/ Ordered by their behest-/ Achieved general rescue for his friends" (1 143-45). If we were able to ignore the context and take their view at face value, then the sense of a deep conflict between the social bonds that will save Philoktetes and the social bonds governing the contemporary world of the Greek army at Troy would be, as many readers have argued, merely an illusion of the psychologically disturbed Philoktetes, who must then be seen as the truly bad teacher.

Odysseus, true to the reasoning of most of the anthropological thinkers, does assume a complete harmony between his own best interest and the best interest of the community as a whole. But to stress this attitude as a basis for arguing that Odysseus is dramatically justified by the whole of the play is to ignore the thrust of the whole play. The myth of the play, even if it were free of innovations, confronts us with and initially negative image of the society in whose interest Odysseus claims to act; at the same time, Sophokles takes pains to dramatize through his characterization of Odysseus the underlying selfish individualism, hypocrisy, and brutality of that society.

Sophokles normally presents Odysseus' conception of success, not in terms of the anthropological standards of what is useful, helpful, or advantageous, but in the strongly pejorative terms of commercial profit and a markedly unheroic victory. Segal $(1981: 304)$ points to the specifically aristocratic bias of this characterization, which, as we have seen, is as old as the Odyssey. Odysseus uses the term for "advantageous" only once and in a context that has distinct dramatic irony when contrasted to Philoktetes' struggle to find what is advantageous to his belly (287-88) or his generous commitment to whatever brings advantage to his friend (659). Odysseus, having won Neoptolemos to his scheme, tells him that in the event of a delay he will send someone who "having practiced deception with respect his clothing" (morphēn dolōsas, 128-29) will look like a captain and speak craftily (130). Neoptolemos should "constantly take up whatever is advantageous in his words" (dekhou ta sumpheronta tōn aei logōn, 131).

satisfactory. Even Bowra (1965: 287), whom Muth otherwise follows closely, recognizes the play's implicit indictment of Odysseus' self-serving egoism. 
Apart from this calculation in trickery and lying, Odysseus' materialism has a less anthropological flavor. He tells Neoptolemos that victory is a sweet possession (81); when his attempt to argue against ethical compunctions seems to fail, he cites profit (kerdos) as the consideration that should override hesitation (lll 11 ). Philoktetes describes the island on which Odysseus marooned him as a place where no merchant can find a business profit (eksempolèsei kerdos, 303). It is as a groveling merchant that Odysseus' representative soon appears, and his devious manner inspires in Philoktetes an all too legitimate fear that he is being "sold in speech" by this merchant (579). The instant Philoktetes recognizes Odysseus, he exclaims "I've been bought and sold!" (978). That this view of Odysseus' behavior is not merely Philoktetes' illusion is strongly suggested by the cruel sarcasm with which Odysseus releases Philoktetes to die alone on Lemnos without his bow:

But victory is my natural need in every case-

Except yours. Now to you I shall willingly yield place.

Release him! Keep your hands off him from now on!

Let him stay. We don't even need you any more,

Inasmuch as we have this bow. For there is

Teucer among us with this particular skill

And I, who consider myself not a bit your inferior

At wielding this bow or at aiming it straight.

Yes! What need is there of you? Walk about Lemnos and good luck!

We must be on our way. And perhaps your heroic prize

May award to me the honor that ought to have been yours.

$(1052-62)$

One may debate whether this is a further deception aimed at persuading Philoktetes to come to Troy or a blunt statement of Odysseus' spurof-the-moment decision to exploit for his own advantage (cf. 1069) Philoktetes' intransigence. ${ }^{93}$ But the narrowly self ish cruelty of his line of reasoning is indisputable. Nothing Odysseus does or says elsewhere in the play contradicts the impression that this speech accurately represents his characteristic way of thinking. Yet Odysseus', and to a lesser degree the chorus's, calculations and values constitute the only evidence we have in the play for those that predominate in the society of the Greek army as a whole. Odysseus' reasoning here is the ugly obverse of the sophistic thought that views society as founded on mutual

\footnotetext{
${ }^{93}$ Lesky (1972: 243-44) says cautiously that the poet gives us no clear answer to this question. Linf orth argues (1956: $135-56)$ emphatically that Odysseus must be only bluffing here; so too Kitto 1956: 124, Hinds 1967: 177, and Calder 1971: 161. Contra, T. Wilamowitz-Moellendorff 1969 [1917]: 304-7, Bowra 1965: 286-87, Knox 1964: 134, and D. Robinson 1969: $45^{-51}$, which I find particularly persuasive.
} 
human need. We have stressed Sophokles' dramatization of the humane consequences in the bonds of pity and af fection established between Philoktetes and Neoptolemos. Here we see a callous calculation of what is not needed (oude sou proskhrèizomen, 1055; ti dèta sou dei? 1060). Philoktetes becomes society's first throw-away person; Odysseus is the man who undertakes here, as he had ten years before, to handle the disposal operations and to glory in the personal profit he will gain from it; for victory is all he "needs" (khreìizon, 1052).

A more obvious aspect of Sophokles' dramatic emphasis on the hypocrisy of Odysseus' claim to work only for the public good is the ironic contrast between Odysseus' and Philoktetes' respective relationship to necessity. Philoktetes, as we have seen, knows the necessity of his dayto-day struggle to survive the threats of the elements $\left(53^{8}\right)$ and to endure the physical pain imposed on him by circumstances (1317). But in relation to human beings he displays an iron commitment to personal freedom which is proof against bribery, force, the threat of death, or even the sincere appeal of a friend. The social bonds he adheres to involve freely volunteered service to his friends, Herakles $(670)$ and Neoptolemos (1404-5). His participation in the Trojan expedition is pointedly presented as this same sort of freely volunteered service (1027). Odysseus, in sharp contrast, himself acknowledges that he participated in the expedition out of necessity (eks anankēs, 73), and Philoktetes reminds the audience that in fact Odysseus had to be tricked as well as forced to participate (1025). This is the man who repeatedly describes himself as a mere servant following orders.

The society of the Greek army as a whole is characterized almost exclusively as an entity that gives orders. The first of these we hear of in the play is the callous order to maroon Philoktetes (6). This same society requires that Neoptolemos serve the orders of Odysseus (hypèretēs, 53, cf. 93-94). Nowhere does Odysseus associate, as most of the anthropologists do, this obligation to subordination with the idea of compensating long-term advantages in a civilized polity. Those advantages are an important theme in the play; but only the chorus, Neoptolemos, and Herakles are permitted to articulate them in contexts in which they are explicitly hostile to or override the political dominance of Odysseus and the Atreidai. Thus Sophokles seems perhaps in the very choice of his myth and certainly in his development of it to echo the most pessimistic of the Sophists, Antiphon and perhaps Thrasymachos. ${ }^{94}$. The

\footnotetext{
94 See Havelock 1957: 23-29 on Thrasymachos and 1957: chap. 10 on Antiphon. See also Moulton 1974 on the shift toward pessimism. Guthrie (HGP 3: esp. 91-92) makes an interesting case for a more sympathetic view of Thrasymachos as parodied in the $R e$ public. Kerferd (1981a: 122) makes the more traditional association with Kallikles; Contra see Furley (83) in Kerferd 1981 b.
} 
state, through a crass calculation of its own needs, which seem synonymous with the convenience of its rulers, imposes horrible suffering on a citizen who is not merely guiltless $(676-86)$ but ready to contribute generously to a common effort (1027). It exacerbates rather than relieves his physical pain; and when the occasion arises which requires a reversal of his exclusion from society, the state is ready to give orders (1 1 44) that violate his self-respect by deceit and force. Like Zeus in the Prometheus, the state is cast in the image of a brutal tyrant, hostile to all the advantages of human society which are symbolized in the hero (Pohlenz 1954: 330, 332).

It is possible to surmise an evolutionary solution of the apparently irreconcilable conflict in the Prometheus; but, as we have seen, Sophokles seems to treat his myth in a way that evokes anthropological speculation about the development of human society but precludes a positive view of the third or contemporary state of that process. The fascination, frustration, and much of the tragic pathos of this play thus depend on Sophokles' paradoxical exploitation of sophistic anthropological speculation. His dramatization of Philoktetes' grim, isolated struggle to survive the threats of beasts and harsh elements poses most absolutely, almost "scientifically," the need of human beings for society; yet the only society available is characterized as subhuman.

\section{The Way Out: The Supersession of the Sophists}

If there is any real resolution of the dilemma posed by this play, and many sensitive modern readers see none, we may approach it by summarizing Sophokles' debts to the Sophists and his departures from them. ${ }^{95}$ Sophokles' response to the Sophists, though not as thorough or explicit as Plato's, moves along lines we see Plato exhausting in the next chapter. Sophokles exploits, as we have seen, the sophistic analysis of the origin and development of society in such a way as to imply a strong condemnation of the Sophist in contemporary society. Although the main thrust of sophistic anthropology was egalitarian, we have seen evidence that some Sophists were willing to equivocate about aristocratic birth in their attempt to demonstrate that even the

\footnotetext{
${ }^{95}$ Linforth's whole study of the play (1956: esp. 95-97) has the primary aim of demonstrating that Sophokles did not and could not accept the traditional ending of the myth, the return of Philoktetes to Troy, as true to the logic of the rest of the myth. The ending we have then is a more or less cynical bow to tradition; T. WilamowitzMoellendorff (1969: 311 ) and Ronnet (1969: 274) agree. Whitman (1951: 187-88) offers the most impressive defense of the ending. See also Pratt 1949: esp. 286-87, Kirkwood 1958: 39, and Winnington-Ingram 1980: 297-303.
} 
well-born needed professional education. Sophokles exploits this equivocation to offer a militant affirmation of inherited excellence. Similarly, he exploits the sophistic analysis of ethical values along lines that culminate in aristocratic absolutism for which metaphysical, that is, divine, validation is claimed.

Sophokles' major transformations of the presocial struggle for survival consist of this downgrading the heavily intellectual emphasis of the Sophists and stressing the extraordinary aristocratic superiority of Philoktetes. Thus, despite the relative obscurity of Philoktetes' family in the broad spectrum of Greek heroes, Philoktetes is described almost at the outset of the play as "perhaps second to none in his noble origins" $(180-81)$. Similarly, though we have noted the caref ul use of the technological vocabulary (tekhnèma, mèkhanaomai, ekseuriskō, pur) to give Philoktetes'struggle an anthropological coloring, Sophokles does not celebrate primarily the intellectual ingeniousness of his hero but his unique courage, which sets him above his enemies..$^{96}$ Thus, when Philoktetes thinks he is about to leave, he is anxious that his young friend look at his cave home to learn (mathēs) how he manifested his uniquely courageous nature (hōs . . e ephun eukardios) and in particular his qualities of daring and endurance (tlènai); he has learned day-to-day acquiescence in sufferings that no one else could even stand to look at (533-38).

The aristocratic slant Sophokles gives to his exploration of the social compact stage is even more striking. Although the chorus, representing in this context the ordinary mass of human beings, are open to spontaneous feelings of pity, they are incapable of acting independently, caught in playing out the lies concocted by their superiors, and in the final analysis committed only to time-serving. It is only Neoptolemos, "son of the best of the Greeks" (3), possessed of "primeval god-sanctioned royal power" $(138-41)$, who is able at last to validate the implications of his inherited nature by responding to pity and affection sufficiently to make the ultimate commitment to his friend's interest. The linguistic emphasis throughout the play on such aristocratic ethical terminology as gennaios, eugenēs, and phūo/phusis in the

\footnotetext{
${ }^{96}$ Letters (1953: 273-74) dourly speaks of Philoktetes as "not just a skill-less Robinson Crusoe, though he has spent so many years without any recorded improvements in his savage economy." Then, more blatantly ignoring the strong emphasis in the play on the struggle to survive, he concludes: "The introvert of Sophokles' play finds occupation enough in brooding over his wrongs." Sophokles in fact has a special problem in his chosen material: he must sharply differentiate his hero's arts of survival from those of the mythic figure who is most traditionally associated with all sorts of sophia. Indeed, Vlastos (1946: 61) speaks of Democritos' concept of sophia as "Ulysses-like resourcefulness." I believe that there is a similar factor at work in the exclusion of allusions to primitive gardening or food gathering: for all his wretchedness, Philoktetes must remain the aristocratic hunter, sharply distinguished from any form of activity that smacks of the peasant.
} 
context of pervasive allusions to paternity tends to mask the sophistic core with a Pindaric overlay. ${ }^{97}$ For, as we have noted, the content of the ethical choices Philoktetes imposes on Neoptolemos owes more to the Sophists than to Homer or Pindar; and the dramatization of the impact of Philoktetes' experience and character on Neoptolemos owes much to sophistic theorizing about educational companionship (sunousia). Yet the bond established between Neoptolemos and Philoktetes is neither explicitly educational nor explicitly a social compact; it is rigorously cast in the mold of traditional heroic, aristocratic male bonding in which the older man is inevitably cast in the role of a father figure and thus a natural educator by example. Tacitly parallel to the more explicitly erotic friendship of Achilles and Patroklos (434), it is more immediately modeled on the friendship of Herakles and Philoktetes $\left(670,143^{6}-37\right) .{ }^{8}$ Sophokles thus seems at pains to imply that the natural consequence of this interaction of two heroic friends is the confirmation of an excellence of character in Neoptolemos that is already his by birth. Neoptolemos' shockingly hypocritical and manipulative behavior is repeatedly presented as an intrusion from the contemporary world; he is the victim of bad education $\left(971,1014^{-15}\right)$ by Odysseus, who, as we have seen, is explicitly characterized as a Sophist.

Generally, bad education and low birth are presented as the chief faults of the third or contemporary level of society. Bad education by the leaders is offered as an explanation for all the city's and the entire army's misconduct $(384-85)$, and the subservience of the chorus to their leaders confirms the fact that this indictment is not merely a lie concocted by Neoptolemos for the immediate situation. The inhumane and manipulative conduct of Odysseus is associated not only with his sophistry $(14,77, \mathrm{cf} .431,1015,1244)$ but repeatedly with his low birth from Sisyphos $(384,417,1311)$. Finally, Sophokles ignores a minor detail of the mythic tradition in order to associate Odysseus with the virtual paradigmatic figure of low birth, Thersites (Gellie 1972: 291-92; contra Huxley 1967: 6).

\footnotetext{
${ }^{97}$ gennaios: $51,475,799,801,1068,1462$; eugenès: $336,604,874$; phuō: 79, 88, 326, 558, 910, 1052, 1074, 1244, 1372 ; ekphuō: 89, 996; phusis: 79, 874, 902, 1310; patēr: 3, 96, $24^{2}, 260,347,434,362,453,468,490,625,996,1284,1311,1314,1365,1371,1430$; Achilles: 4, 50, 57, 62, 26o, 328, 331, 364, 542, 582, 940, 1066, $1220,1237,1312,1443$; Poias: 5, 263, 318, 329, 461, 1 230, $1261,1410,1430$; Sisyphos: 384 (by implication), 417 , 1311. Not every instance in a Greek tragedy of address to a character by reference to his paternity must be seen as implying a belief in inherited excellence. In this play, however, where the theme is so explicit, I believe that the cumulative impact of these allusions is quite striking.

${ }^{98}$ Calder (197 1: 169 n. 88) reviews with savage skepticism the attempts of "refined critics" to find an "erotic" dimension to the play. It takes, I think, something quite different from refinement to deny the general homoerotic pattern of Greek aristocratic culture, though to be sure the reference in the Philoktetes is quite indirect.
} 
Sophokles' solution of the conflict between the implications, on the one hand, of the first and second stage of his anthropology and, on the other, of those of the third stage lies in the radically hierarchical perspective he has built into the analysis of society and develops through his control of the dramatic action. By the end of that action he has claimed, with a religiously archaizing self-consciousness nearer Plato than Homer, the absolute validation of this social and political hierarchy in the will of Zeus.

The low point of pessimism in the play occurs in a digression of some fifty lines $(410-55)$ on the effects of war, a passage that has long been recognized as vividly contemporary in its impact. Achilles is dead, Ajax is dead, Antilochos is dead and his father Nestor has lost his position as the respected adviser. Patroklos too is dead. But Diomedes, Odysseus, the Atreidai, and Thersites flourish. The obvious human lesson (ekdidaksō) from these facts is stated first by Neoptolemos: "In a brief saying / I'll draw the lesson: of its own will War / Seizes no worthless man, but takes the good always" (435-37). The bitter, despairing implication for the governance of the universe is in turn stated by Philoktetes:

Nothing bad has ever perished.

Rather, the gcds carefully bundle them up to shield them And somehow take delight in turning back from Hades The jaded, criminal elements; while the right-acting, The decent sort, they dispatch there constantly.

What reckoning must I make of this? How shall I praise, when

In setting praise on divinity, I find the gods bad?

And as if the point was not clear and sweeping enough, Neoptolemos sums up the case for despair in a neat, redundant Gorgianic truism: "Where the worse over better rules in might / The worthy all perish and the trickster's ${ }^{99}$ right" $\left(45^{6-57}\right)$.

Commentators and critics occasionally cite the contemporary evidence that would justify so bitter a view of the effect of a long war. ${ }^{100}$ Some (e.g., Calder 1971) see this speech as merely a further instance of Neoptolemos' deceit. What is rarely pointed out is how fully these sentiments correspond to Odysseus' analysis of present realities:

Son of a noble father, I too once, when young,

Kept my tongue unemployed and my hand a hard worker.

99I retain the deinos of the manuscripts where Jebb reads deilos.

${ }^{100}$ See Jebb of 435 ; Webster 1970 on 436 ; Bowra 1965: 277, 286. M. H. Jameson's 1956 article contains a wealth of contemporary data, but it also suggests some contemporary grounds for the relative optimism of the ending. 
Now that I've come to the test, I see that

The tongue, not action, has total sway over men.

All three major characters look at the reality of the war and conclude that moral values and courage in action count for nothing in the struggle for survival and success. Both Odysseus-with his commitment to verbal manipulation and his guardian gods, Tricky Hermes and Political Athena-and Philoktetes-with his direct experience of gross injustice apparently triumphant-infer that the gods uphold such an analysis. But it is the full exploration of Philoktetes' own successful battle to overcome the worst assaults of a corrupt contemporary society, and finally, his capacity to inspire the emergence of the highest social virtues in the promising noble pupil which lay the emotional and intellectual foundations for the tremendous, utopian affirmation of aristocratic human worth-an affirmation that sweeps away the pettiness and viciousness of Odysseus in the epiphany of an apotheosized Herakles. ${ }^{101}$

Philoktetes himself has come to recognize the invasion of a reality overriding the shortsighted calculations of the Atreidai. Though he rejects bitterly what he perceives as Odysseus' cynical exploitation of religion for gross ends (991-92) (see Spira 1960: 22), he is soon moved from his despair to perceive an implicit divine concern for right in the "divine goad" that has prodded Odysseus to come for the crippled, foul-smelling man who had interfered with their rituals (1031-39). It is the quasi-scientific, existential demonstration of Philoktetes' absolute superiority in circumstances in which he is stripped of every social and religious support that endow this divine validation with the aura of something more solid than pious wish fulfillment. By the end of the play, it is dramatically credible that Philoktetes is needed by the Greek army, not just through some quirk of fate or, as Odysseus seems to think, by virtue of the fact that he happens to possess a magic weapon. Philoktetes is dramatically represented as the best human being left alive, and the bow of Herakles is not the cause of his superiority but the clearest external symbol of it. ${ }^{102}$ Similarly, Philoktetes' wound is the clearest symbol of his need for society, of the intolerable pain of isolation from the positive virtues of communal life.

\footnotetext{
${ }^{101}$ I had hoped to pass over in well-deserved silence the absurd thesis of Errandonea (1956) that the appearance of Herakles represents the final ploy of a disguised Odysseus; but alas a later discussion of the play, Shucard's (1974), inf orms us: "Errandonea . . . brilliantly shows that Herakles is actually Odysseus" (135 n. 20). I do not know how one would set about refuting so inherently preposterous a view; I only record here that I am aware of it and do not see any merit in it. In general, Gardiner is quite sensible about what is explicit and what can be inferred from the text of a tragedy $(1987: 37,47-48)$.

${ }^{102}$ Kirkwood (1958: 77) is surely right in describing Helenus' prophecy as "a commentary on Philoktetes' greatness, just as his possession of the weapons of Herakles is."
} 
The appearance of Herakles confirms on an absolute plane the data resulting from Sophokles' aristocratic exploration of the presocial and social compact phases of the struggle to survive. Though this solution grows organically from Sophokles' particular "thinking through" sophistic social and political teachings, the appearance of Herakles is the most self-consciously archaizing aspect of the play: "epic," "heroic," "aristocratic," "religious"- the antitheses of the style and values one associates with the Sophists. The tonality of the play is decisively shifted from a world apparently dominated by the Atreidai and Odysseus. In perhaps Sophokles' most grimly realistic play, if by that characterization we mean focused on the ugliest contemporary realities, this ending succeeds in achieving an eminently ideological aura of grandeur drawn from the reservoir of aristocratic myth: Zeus's favorite son affirms the justice of Zeus.

Though critics have often spoken crudely of orders from Zeus delivered by Herakles, the tone of address recalls the deferential courtesy of some Homeric exchanges between gods and heroes (Snell 1960: $32) .{ }^{103}$ Herakles' first words, responding to Neoptolemos' injunction to Philoktetes to "bid the land farewell and start out" (1408), emphasize the option of their proceeding on their chosen course: "Not yet, at least until you have heard our tale" (1409-10), and then add a deferential vocative, "son of Poias." Again, after explaining who he is and why he has come, he uses a polite Homeric injunction for a sympathetic hearing (epakouson). ${ }^{104}$ After a play shot through with sophistic exploration of the powers and limitations of logos, Herakles describes his speechand Philoktetes repeats the word-by the archaic, heroic term muthoi (1410, 1417, 1447; Winnington-Ingram 1956: 633 n. 1). Herakles' prime motive in coming is designated by the word kharis, which conveys the reciprocity of concern characteristic of heroic friends and at the same time the peculiar Greek notion of a divine grace reserved for heroes, for winners by birth. The phrase used for the will of Zeus (ta Dios ... bouleumata) recalls the Dios boule of the Iliad, which there describes, not the cynical aim of ridding the earth of excess population found in the Kupria (Homeri Opera 5:1 1 7) but Zeus' commitment to val-

${ }^{103}$ T. Wilamowitz-Moellendorff ( $\left.1969: 311\right)$ speaks misleadingly of Herakles' coming to command (befehlen) Philoktetes to go to Troy. He is followed by Grene (1967: 140) and Gellie (1972: 157) among others. K. Alt (1961: 173) emphasizes rightly the purely persuasive tone of Herakles' speech; but since Kitto (1956: 137) seems to have convinced too many readers that there is nothing of interest in Herakles' speech, $I$ have considered it in some detail.

${ }^{104}$ LSJ s.v. 4 suggest the de facto sense of "obey" citing this passage; but the only preSophoklean passages cited, Il. 2.143 and Hesiod $O p .275$, do not justify seeing more than the usual confidence conveyed by the word that a careful hearing will win agreement. In the case of the Hesiodic passage, the author is clearly whistling in the wind. 
idating Achilles' absolute superiority in the face of rejection and injury by the highest political authority in his society (Whitman 1958: 132-37).

Like traditional heroic advisers such as Nestor or Phoenix who can be and sometimes are ignored, Herakles prefaces his detailed advice with a paradigmatic tale. In this case, the tale is the speaker's own career and recalls broadly Herakles' similar exhortation to the heroic Odysseus in the underworld $\left(\mathrm{Od} .11 .615^{-26}\right)$. The figure who for Achilles in the Iliad represents the ultimate futility of birth from divinity (Il. 18.117-19) spurs the hero of the Odyssey with a tale of sufferings finally compensated in dazzling triumph. Here the specific inducements are strictly individual and heroic: immortal success and a life of glory (1420-21). Philoktetes' real superiority will be validated by the whole community, thus answering earlier legitimate fears of the probability of further mistreatment by the Atreidai and Odysseus. The phrase used to express this (aretēi te prōtos ekkritheis strateumatos, 1425) recalls a Pindaric description of a winner in the great games (Ne. 7.7) and, combined with a promise of winning the aristeia (1429), offers reassurance that the dark fate of Ajax alluded to earlier in the play (410-15) will not be repeated in the case of Philoktetes. ${ }^{105}$ The honorific allusion to Philoktetes' father with which Herakles begins is echoed in the full reassurance that not only is Poias alive but Philoktetes, unlike so many other heroes, will succeed in returning to his father and his home (1430). Herakles then lays a specific obligation on Philoktetes, to dedicate a thank-offering from the spoils for Herakles' bow at the scene of his funeral pyre (1431-33). The allusion reinforces the personal sense of kharis at the outset of the speech (1413) by reminding the audience of the service that won Philoktetes his bow.

Enjoining a parallel mutual dependence on Philoktetes and Neoptolemos expressed with a heroic lion simile, Herakles announces that he will personally send the divine doctor to cure Philoktetes' wound. This action is linked causally to the only explicit allusion in the speech to the fate of Troy's fall: "For it [Ilion] is fated a second time to be taken by my bow" (1438-39). The very vagueness of such a fate, its air of sheer mystery and individual heroic fetishism, should preclude reading into this speech the faintest hint of divine concern for the interests of the Atreidai and Odysseus. Indeed the final solemn injunction to show reverence to the gods in the sacking of Troy $\left(144^{0}-44\right)$ is distinctly ominous. It recalls the many desecrations of the final night of Troy which spell later disaster for so many Greek chieftains including the Atreidai,

\footnotetext{
${ }^{105}$ It is not necessary to retain the normally bracketed lines at ${ }^{136} 5^{-6} 6$ (see Jebb's appendix ad loc.) to see in the allusion to Ajax's death an adequate reference for the audience to the Hoplon krisis. They will recall Neoptolemos' emphasis in his lie on Odysseus' possession of his father's arms.
} 
Odysseus, and Neoptolemos himself. The allusion is at best only implicit, but if it is present, it focuses awesomely the final ambiguity of Sophokles' vision: on the one hand, the divine validation of the good Philoktetes and punishment of the evil powers that marooned him are reaffirmed; on the other hand, the fragility, the terrible vulnerability to corruption, of the noble young phusis is confirmed in a dark allusion to Neoptolemus' subsequent development into the most impious of all the criminals at Troy. ${ }^{106}$

Apart from this possible dark note, the utopian direction of the play's resolution is clearly dominant in Philoktetes' full achievement of sōtèria and Neoptolemos' realization of the best potentialities of his noble phusis. Herakles furnishes absolute, "divine" confirmation of both by recalling in style and content the whole aristocratic tradition of myths celebrating the dependence of society on the single superior individual and the intense suffering that unique superiority entailednot as in Aeschylus for the community, but for the superior individual himself or herself. The pragmatic political consequences of such an ending may appear to be a simple glorification of the old-time religion and the old-time ruling class. Yet anyone who responded to the agonizing and profound exploration of all the new intellectual and political realities threatening the underlying assumptions of the old views must have recognized that the affirmation of the ending is not naively or cheaply won. Sophokles' ideological counteroffensive is eminently indirect and cautiously circumscribed with what might almost be called escape-clause ambiguities. Depending on how far one takes the allusion to the crimes committed in the destruction of Troy, one may indeed subscribe to Winnington-Ingram's perception of a preponderantly ironic vision in Sophokles.

Philoktetes' final farewell to his island is in one sense a reminder of the whole anthropological metaphor that framed the hero's struggle to survive and make social ties possible. At the same time, the transformation of the formerly harsh, impersonal arena of that isolated struggle into a mythic, animate, and benign array of divine presences who

\footnotetext{
${ }^{106} \mathrm{Jebb}$ cites with apparent approval the observation of the scholia: "This warning derives force from the tradition that, af ter the fall of Troy, Neoptolemos 'slew Priam, when he had taken refuge at the altar of Zeus herkeios.' "Neither Jebb nor, as far as I can recall, anyone else has explored the important implications for the whole education motif in the play of such an allusion. Craik rightly observes that, as far as concerns Sophokles' "conviction ... that the preeminent principle governing a man's course of action is his inborn inherited tendency to nobility or the reverse, ... the only new element is the prominence given ... to the recognition that phusis can be corrupted and diverted from its proper track" (1980: 253). She does not, however, speak to this passage. Christian Wolff nicely spells out the ambiguities of the lion image by reviewing its traditional associations (1979: 144-50).
} 
may guarantee the sōterria implicit in the hero's return suggests the poet's own will to transcend and leave behind the Sophists from whom he had learned so much. He has turned their most powerful grounds for endorsing an egalitarian society based on persuasion and education into a ringing affirmation of the old hierarchies, which, in the midst of democracy's demise, were asserting their claims to power on new ideological foundations.

\section{The Athens of 409 B.c.}

Those few critics who have explored possible connections between the world and the text (Said 1983) of the Philoktetes have understandably been tempted by what might be called the roman à clef approach, identifying the protagonists with this or that political figure. One obvious drawback of this approach is that, for every detail that seems to support a fit, there are others so grossly incongruous that, as in the case of older attempts at historicizing Pindar, the whole enterprise of considering the relation of the literary text to the society in which and for which it was produced is discredited. We are then invited to fall back on the "Olympian" Sophokles, "unpolitical' as far as any Athenian of that generation could be unpolitical" (Ehrenberg 1954: 138). Yet, as I have tried to demonstrate, the level on which the Athenian dramatic text responds to its context is highly abstracted from the immediate, dayto-day struggles of the assembly and the war. As an ideological construct, it engages in the politics of world views. It picks and chooses from the available concrete data of the political, social, and economic realities of Athens in its twenty-second year of war-ignoring much that leaves no trace, bracketing other data in a structured silence that requires a search for symptoms (Macherey 1978), and constructing a dream world out of other data which is thus distorted past recognition.

If we seek to construct what we can from the surviving sources of the realities of class warfare both internal to Athens and external in the war against the Spartan alliance, a few potentially relevant elements stand out. The tragic trade-off envisioned in the Eumenides, in which war with Sparta emerges as the price for banishing war at home between the Athenian rich and poor, had by the time of the Philoktetes utterly collapsed. The Sicilian disaster of 413 B.c. had so strengthened the hands of the oligarchs that they succeeded in having government authority turned over to special councillors (Probouloi), of whom one was the octogenarian Sophokles (Aristotle Rhet. 1419a-26). In $4^{11}$ B.c., the Four Hundred took over, initiated a bloodbath, and did their best to turn Athens over to Sparta. 
Aristotle's tantalizing evidence about Sophokles' own apparent complicity in this right-wing coup curiously parallels mutatis mutandisPlato's relation, a few years later, to the even more violent oligarchic rule of the thirty tyrants. Aristotle, in a passage of the Rhetoric that reviews various ways of using interrogation, informs us, "When Sophokles was asked by Peisander [one of the leaders of the coup] if he had not voted as the other porbouloi had to set up the 40o, he answered yes. 'Why?' said Peisander, 'Didn't this seem evil to you?' He answered yes. 'Well then,' said Peisander, 'Didn't you commit evil?' 'Yes I did,' Sophokles said, 'For there was nothing better"' (1419a26-30). Calder (1971) is surely wrong to conclude from this passage that the excesses of these aristocrats turned Sophokles into a committed democrat who apologizes for his complicity through the Philoktetes. Yet the reminder of Sophokles' direct political involvement, shortly before the play, is valuable and legitimate as a caution for those readers inclined to view Sophokles as a figure of Olympian distance. To me the parallel to Plato-who was invited by his uncle Kritias to join the Thirty, hesitantly declined, but soon became repelled by their behavior (Epist. 7) is more suggestive: a clear demonstration of the capacity of the present aristocracy for amoral ferocity worse than the worst follies of the democracy does not bring him any closer to the democracy, for which he retains at best a patronizing pity. Rather, Sophokles, like Plato, turns to an in depth "thinking through" the most intellectually rigorous critique of aristocracy produced by democratic theory only to use it in an attempt to establish a solider ground in anthropology and educational theory for the principle of inherited excellence.

Shortly after the coup of the Four Hundred, when their policies had utterly failed, power was entrusted to a so-called moderate oligarchy of Five Thousand. Nothing reveals more clearly the class character of the Athenian empire (Ste. Croix 1954-55:1-41) or the real stakes in the war than the role of Samos and other so-called "allies" of Athens in the fall of the Four Hundred. The Samian demos revolted in 412 B.c. against their big landowners (geomoroi). The success of this revolution spread to the sailors of the Athenian fleet stationed at Samos. The sailors threw out their oligarchic of ficers and elected democrats: "In consequence the fleet, the instrument of Athenian power, stood as the bulwark of democracy, in opposition to the native city governed by the oligarchs!" (Bengston 1988: 150). Other crucial reverses for the Four Hundred resulted from their imposition of oligarchies on allied cities such as Thasos, which revolted to get rid of both oligarchs and Athenian tribute all at once. An ultimatum from the Athenian fleet at Samos under Alcibiades set in motion the final discomfiture of the Four Hundred, which was sped on, to be sure, by the loss of Euboea 
(Thucycides 8.87-97). The naval successes of Thrasyboulos and Alcibiades in 411 and 410 B.c. led to the restoration of the full democracy in July of 410 .

As the nephew of Perikles, Alcibiades was certainly the scion of one of the most distinguished aristocratic families in Athens. As the victim of jealous plotting that caused his exile and sentence of death in absentia at the outset of the great expedition to Sicily and one recently associated with an island symbolic of democratic integrity, he has perhaps inevitably occurred to some as the model for Philoktetes. ${ }^{107}$ But the consequences of taking such an identification seriously are grotesque. What could be further from the grim isolation and utterly uncompromising integrity imparted to the dramatic character of Sophokles' Philoktetes than the truly amazing array of manipulations and tergiversations of Alcibiades' whole career, especially between 413 and 410? Moreover, Alcibiades' successes as a flamboyant demagogue are hard indeed to square with the dour image of the "miseducated" and opportunistic demos evoked in the play.

More ingenious but equally unsatisfactory is the effort to see Perikles' son and namesake as the inspiration of Neoptolemos (M. H. Jameson 1956: 222-24). This Perikles was the result of his father's extramarital liaison with Aspasia and was only retroactively declared legitimate by the assembly out of pity for the elder Perikles' loss of all his legitimate sons in the plague (Plutarch Per. 37). The scholar who proposed this identification gives one of the best pieces of evidence against it: "In Eupolis' Demi of 412 B.C. . . Pericles asks a newcomer to the underworld if his bastard son still lives. 'He does,' is the answer, 'and would be a man by now if he were not ashamed of his harlot mother"' (M. H. Jameson 1956: 223). In view of the extraordinary bias against Aspasia and in general against mixed birth on the part at least of non-aristocratic Athenians, it strikes me as highly unlikely that a figure still mocked for his illegitimate birth as late as 412 B.c. would easily come to mind three years later as the embodiment of aristocratic excellence of birth.

But such specific identifications are a snare and a delusion. The broader picture suggests an all but total alienation from the whole spectrum of deceitful, ambitious, and potentially murderous leadership of both the oligarchic and democratic factions on the grounds that the war has already destroyed virtually all the good (cf. Ph. 446-50o). Both the epigraphic and historical sources suggest that the old aristocracy had been substantially diminished by the long war (MacKendrick

\footnotetext{
${ }^{107}$ M. H. Jameson (1956: 219 ) traces this identification back to Lebeau in the eighteenth century and offers excellent reasons for rejecting it.
} 
1969: 3). The absence of patriotic appeals beside the ultimately personal rationale of fered by Herakles for successfully concluding the war against Troy suggests at best a grudging acquiescence to the dogged determination of the demos to reject all opportunities for peace. But, as I have tried to demonstrate, the primary level at which the text of the play responds to the present is, first, its full-scale subversion of the sophistic anthropology to the extent that that doctrine offered a warrant for an egalitarian society based on open debate and, second, its tentative affirmation that the combination of inherited excellence with the right education and some superhuman support just might salvage an otherwise hopelessly corrupt body politic. The utopian nostalgia for the Pindaric securities of noble birth beside the grimly realistic appraisal of the social, political, and in the broadest sense educational forces arrayed against that elite point forward to the far more rigorous attempt of Plato to solve this ideological crisis of the ruling elite.

\section{The Utopian Moment}

As the foregoing analysis suggests, the utopian element in this play seems especially thin-archaic even for its own time. A vision of an allmale world of born aristocrats exercising political supremacy through martial prowess offers most of us nothing new with which to chart a course toward an ampler, more just world. Yet the haunting and enduring appeal on this play is inseparable not only from this vision but from the calculated ambiguities of its integration of sophistic anthropology. Sophokles succeeds, in no small measure precisely through the anthropological imagery of unaccommodated man, in transforming the Pindaric aristocratic hero into an image of radical human integrity. We respond to the play's celebration of a capacity for sheer endurance, for an existential affirmation of consciously chosen values against the combined violence of raw nature and of human society at its most vicious and oppressive. This icon of human authenticity is inextricably linked to hideous and repellent physical suffering. The dramatization of the power of such a figure to inspire another human being with such pity and such admiration that he is at last willing to forego all the seductions of assured success and face all the risks of repudiating all established authority remains for me incomparably moving in an age so marked by both systematic, state-supported torture and heroic revolutionary struggle to affirm elemental human rights. 